Published in Journal of Electromyography and Kinesiology

http://www.sciencedirect.com/science/article/pii/S1050641117301736

DOI: $10.1016 /$ j.jelekin.2017.08.005

Available online 18 August 2017

\title{
Normalizing shoulder EMG: an optimal set of maximum isometric voluntary contraction tests considering reproducibility
}

Cédric Schwartz ${ }^{1}\left({ }^{*}\right)$, François Tubez ${ }^{1,2}$, François-Charles Wang ${ }^{3}$, Jean-Louis Croisier ${ }^{1,2}$, Olivier Brüls ${ }^{1,4}$, Vincent Denoël ${ }^{1,5}$, Bénédicte Forthomme ${ }^{1,2}$

1. Laboratoire d'Analyse du Mouvement Humain, University of Liège, Liège, Belgium

2. Department of Physical Medicine and Rehabilitation, University of Liège, Liège, Belgium

3. Department of Physical Medicine and Sports Traumatology, University Hospital of Liège, Liège, Belgium

4. Department of Aerospace and Mechanical Engineering, University of Liège, Liège, Belgium

5. Department of Architecture, Geology, Environment and Constructions, University of Liège, Liège, Belgium

$(*)$ Corresponding author 


\begin{abstract}
Normalization of the electromyography (EMG) signal is often performed relatively to maximal voluntary activations (MVA) obtained during maximum isometric voluntary contraction (MVIC). The first aim was to provide an inter-session reproducible protocol to normalize the signal of eight shoulder muscles. The protocol should also lead to a level of activation $>90 \%$ of MVA for $>90 \%$ of the volunteers. The second aim was to evaluate the influence of the method used to extract the MVA from the EMG envelope on the normalized EMG signal. Thirteen volunteers performed 12 MVICs twice (one-week interval). Several time constants (100 ms to $2 \mathrm{~s})$ were compared when extracting the MVA from the EMG envelope. The EMG activity was also acquired during an arm elevation. Our results show that a combination of nine MVIC tests was required to meet our requirements including reproducibility. Both the number of MVIC tests and the size of the time constant influence the normalized EMG signal during the dynamic activity (variations up to 15\%). A time constant of $1 \mathrm{~s}$ was a good compromise to extract the MVA. These findings are valuable to improve the reproducibility of EMG signal normalization.
\end{abstract}




\section{Introduction}

The shoulder muscles play an important part in the stability of the shoulder joint and are involved in shoulder related pathologies. Electromyography (EMG) is a common tool to evaluate the muscle contraction intensity (De Luca, 1993). There is, however, no unequivocal relationship between the amplitude of the electrical signal and the force exerted by the muscle because of intrinsic and extrinsic factors (Halaki and Ginn, 2012). Consequently, electromyographic recordings need to be normalized if comparisons between subjects or of one subject at different times are sought. Several methods have been used to normalize the EMG signal (including maximal and submaximal contractions). The reader can refer to (Burden, 2010) and (Halaki and Ginn, 2012) for more insights concerning the advantages and disadvantages of each method. Rather than expressing the EMG signal relatively to a reference EMG activation, the EMG signal is also sometimes expressed relatively to the maximal voluntary contraction (force) using a power regression model derived from the measurements made during a ramp procedure (Mathiassen et al., 1995). Maximum voluntary isometric contractions (MVIC) are commonly used (Burden, 2010) because it allows to compare muscle activity levels between muscles, tasks and individuals (Halaki and Ginn, 2012).

A key factor to use EMG evaluations for rehabilitation or clinical trials is the ability to obtain reliable measurements over time. Previous studies on the normalization of the EMG signal of the shoulder have mainly focused on the tests leading to maximal activations (Boettcher et al., 2008; Castelein et al., 2015; Dal Maso et al., 2016; Ekstrom et al., 2005). To our knowledge, little has been done to evaluate the reproducibility of the normalization procedures. Ekstrom et al. showed that a good intra-session repeatability can be expected (Ekstrom et al., 2005). Power regression procedures present a lower intra-day repeatability than a maximal voluntary activation (MVA) (Bao et al., 1995). However, and despite its importance, no studies have investigated the inter-session repeatability of the MVA determination.

The raw EMG signal is usually not directly used and is first post-processed to obtain the signal linear envelope (i.e. Root Mean Square - RMS, Low Pass filtering, ...). As demonstrated by Fischer et al. for the deltoid muscle during a sub-maximal exertion, the method used to extract the peak activation from the EMG envelope influences the intra-session repeatability (Fischer et al., 2010). The influence of these choices on the inter-session repeatability of the normalization procedure has not been evaluated yet. Furthermore, it should be underlined that no consensus exists on how the MVA should then be extracted from the EMG envelope and the exact process varies from one author to another.

The first objective of this study was to test the inter-session reproducibility of several combinations of MVIC tests. The second objective was to evaluate the influence of some MVA peak extraction techniques on the reproducibility. In addition to these two main goals, the 
influence of the choice of the retained MVIC tests and of the MVA peak extraction technique on the interpretation of the muscle level of activity was evaluated during arm elevation.

\section{Material and methods}

\subsection{Participants}

Thirteen male volunteers $(25.3 \pm 3.7$ years, $76.2 \pm 11.5 \mathrm{~kg}, 1.80 \pm 0.05 \mathrm{~m})$ were recruited. None of them had a painful shoulder or a history of surgery or injury at their dominant (tested) shoulder. The study was approved by the local ethics committee and each participant was informed of the details of the study and provided signed consent before participation.

\subsection{Instrumentation}

The EMG signal was collected with Trigno Standard and Trigno Mini sensors (Delsys, Boston, MA, USA) using silver-contact wireless bipolar bar electrodes with fixed $10 \mathrm{~mm}$ inter-electrode spacing. Eight of the main superficial muscles of the shoulder were investigated: upper and lower trapezius, serratus anterior, pectoralis major, latissimus dorsi, anterior and middle deltoid and infraspinatus. This set of muscles includes a major motor muscle of the shoulder (deltoid) as well as agonist and antagonist rotators of the shoulder (pectoralis major, latissimus dorsi, infraspinatus). Scapula stabilizer muscles (trapezius, serratus anterior), which are key muscles for studying scapular dyskinesis, are also included. Data was acquired at a sample frequency of $1000 \mathrm{~Hz}$. Surface electrodes were positioned following Barbero et al. recommendations (Barbero et al., 2012).

The kinematics of the arm was measured using a 3D optoelectronic system (Charnwood Dynamics, Rothley, UK) composed of four CX1 units and two active (infrared) markers. Each CX1 alone is able to evaluate the 3D position of a marker. Using several units improve the overall accuracy of the measurements (Schwartz et al., 2015). This 3D system has been shown to be an accurate evaluation tool (Schwartz et al., 2015). The 2 markers were placed $3 \mathrm{~cm}$ below the roof of the acromion and on the lateral humeral epicondyle. Data was acquired at $100 \mathrm{~Hz}$.

\subsection{MVIC tests}

Twelve MVIC tests were used in this study as described in Table 1 and illustrated in Figure 1. To limit a possible influence of the investigator, the MVIC test positions were maintained using a steel structure rather than manual pressure. It was possible to adapt the structure to both the test positions and the specific size of the volunteers. Before starting the MVIC tests, the volunteers performed a warm-up composed of 15 elevations in the sagittal and frontal planes, 15 abductions in the horizontal plane and finally 15 internal and external rotations with an elastic band. Before each test position, the volunteers were asked to perform three increasing 
sub-maximum trials to get used to the exercise and effort. Then, three trials of $5 \mathrm{~s}$ were performed for each test position. The volunteers were asked to increase the exerted force during the first two seconds and maintain maximal force during the last three seconds. During the trials, the volunteers were given verbal encouragement. To avoid fatigue, a minimum of $30 \mathrm{~s}$ and $3 \mathrm{~min}$ rest intervals were provided between each trial and each MVIC test position respectively. The order of the positions was randomized across the volunteers.

Table 1: Description of the Maximum Voluntary Isometric Contraction (MVIC) tests.

\begin{tabular}{|c|c|c|c|}
\hline Id & Name & Position & Description \\
\hline 1 & $\begin{array}{l}\text { Empty can } \\
\text { (Dal Maso et al., 2016) }\end{array}$ & Seated & $\begin{array}{l}\text { Shoulder abducted at } 90^{\circ} \text { in the scapular plane, internally rotated } \\
\text { and elbow extended. Arm abduction with resistance applied at the } \\
\text { wrist. }\end{array}$ \\
\hline 2 & $\begin{array}{l}\text { Extension prone } \\
\text { (Park and Yoo, 2013) }\end{array}$ & Prone & $\begin{array}{l}\text { Arm along the body. Arm extension with resistance applied at the } \\
\text { wrist. }\end{array}$ \\
\hline 3 & $\begin{array}{l}\text { Seated U } 90^{\circ} \\
\text { (Kelly et al., 1996) }\end{array}$ & Seated & $\begin{array}{l}\text { Arm flexed at } 90^{\circ} \text {. Arm flexion with resistance applied at the } \\
\text { elbow. }\end{array}$ \\
\hline 4 & $\begin{array}{l}\text { Palm press } \\
\text { (Boettcher et al., 2008) }\end{array}$ & Seated & $\begin{array}{l}\text { Arms flexed at } 90^{\circ} \text {. Arms horizontal adduction with resistance } \\
\text { applied at the hands. }\end{array}$ \\
\hline 5 & $\begin{array}{l}\text { Prone V-thumbs up } \\
\text { (Castelein et al., 2015) }\end{array}$ & Prone & $\begin{array}{l}\text { Arm flexed and in line with lower trapezius muscle fibers. Scapular } \\
\text { retraction with resistance applied on the upper part of the } \\
\text { scapular spine. }\end{array}$ \\
\hline 6 & $\begin{array}{l}\text { Pull down } \\
\text { (Park and Yoo, 2013) }\end{array}$ & Seated & $\begin{array}{l}\text { Arm abducted at } 90^{\circ} \text { and elbow flexed at } 90^{\circ} \text {. Arm adduction with } \\
\text { resistance applied at the elbow. }\end{array}$ \\
\hline 7 & $\begin{array}{l}\text { Push forward } \\
\text { (Ekstrom et al., 2005) }\end{array}$ & Prone & $\begin{array}{l}\text { Arm flexed at } 90^{\circ} \text { with forearm extended. Scapular protraction } \\
\text { with resistance applied at the hand. }\end{array}$ \\
\hline 8 & $\begin{array}{l}\text { Rotation } 0^{\circ} \\
\text { (Boettcher et al., 2008) }\end{array}$ & Seated & $\begin{array}{l}\text { Arm along the side with elbow flexed at } 90^{\circ} \text {. Arm external rotation } \\
\text { with resistance applied at the wrist. }\end{array}$ \\
\hline 9 & $\begin{array}{l}\text { Rotation } 90^{\circ} \\
\text { (Johnson et al., 2011) }\end{array}$ & Seated & $\begin{array}{l}\text { Shoulder abducted at } 90^{\circ} \text { and externally rotated at } 45^{\circ} \text { and elbow } \\
\text { flexed at } 90^{\circ} \text {. Arm external rotation with resistance applied at the } \\
\text { wrist. }\end{array}$ \\
\hline 10 & $\begin{array}{l}\text { Seated T } \\
\text { (Castelein et al., 2015) }\end{array}$ & Seated & $\begin{array}{l}\text { Arm abducted at } 90^{\circ} \text {. Arm abduction with resistance applied at the } \\
\text { elbow. }\end{array}$ \\
\hline 11 & $\begin{array}{l}\text { Seated U } 125^{\circ} \\
\text { (Boettcher et al., 2008) }\end{array}$ & Seated & $\begin{array}{l}\text { Arm flexed at } 125^{\circ} \text {. Arm flexion with resistance applied at the } \\
\text { elbow. }\end{array}$ \\
\hline 12 & $\begin{array}{l}\text { Shoulder shrug } \\
\text { (Ekstrom et al., 2005) }\end{array}$ & Seated & $\begin{array}{l}\text { Arm along the side. Scapular elevation with resistance applied at } \\
\text { the acromion. }\end{array}$ \\
\hline
\end{tabular}




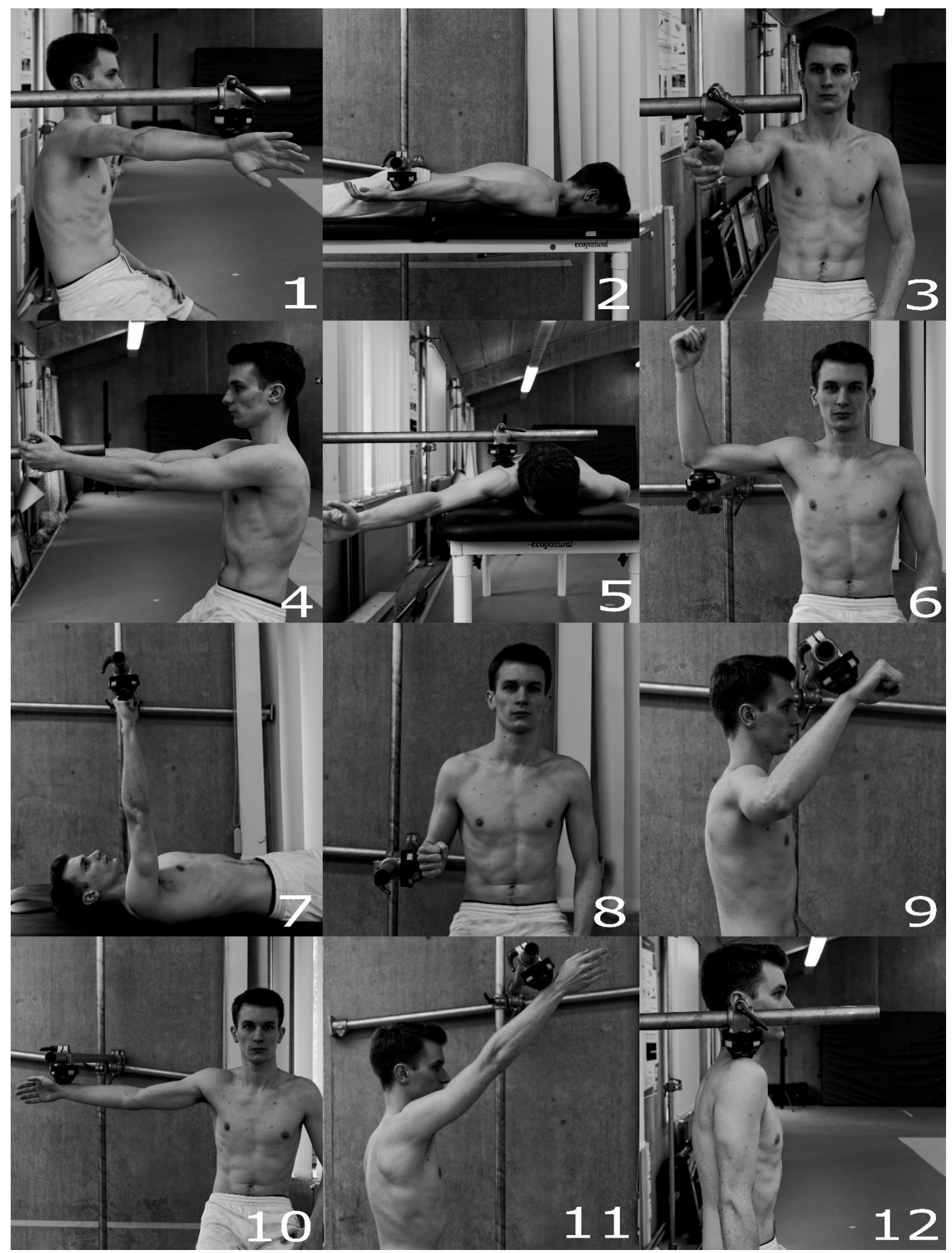

Figure 1: Illustration of the Maximum Voluntary Isometric Contraction tests: (1) empty can, (2) extension prone, (3) seated $U 90^{\circ}$, (4) palm press, (5) prone $V$-thumb up, (6) pull down, (7) push forward, (8) rotation $0^{\circ},(9)$ rotation $90^{\circ},(10)$ seated $T,(11)$ seated $U 125^{\circ},(12)$ shoulder shrug. 
To evaluate the repeatability of the MVA estimations, the volunteers were evaluated again with the same protocol (same MVIC tests order than during the first session) seven days after the first test.

\subsection{Kinematics tests}

The volunteers were asked to perform five consecutive arm elevations in the scapular plane on their dominant side at a self-selected speed. The mean arm elevation speed was $87.5+/-$ $30.2 \%$. The volunteers moved actively their arm up to their maximal range of motion. They were also asked to avoid thoracic compensation when maximal amplitude was reached. A vertical bar served as a guide during the arm raising and lowering. The kinematic tests were only performed during the first evaluation session.

\subsection{Signal and statistical analyses}

The EMG signal was first band pass filtered $(20-500 \mathrm{~Hz}$, zero-phase 4th order Butterworth) and then processed using a root-mean-square algorithm (100 ms moving window) (Castelein et al., 2015). Then, the average EMG envelope over a time window (moving average filter) was calculated during each MVIC trial for each muscle. Four window sizes were tested: $100 \mathrm{~ms}$, $500 \mathrm{~ms}, 1 \mathrm{~s}$ and $2 \mathrm{~s}$. The activation level of each muscle was then defined as the peak value of the processed signal among the three trials. The muscle activation level during each MVIC trial was then expressed as a percentage of the MVA found among all the MVIC trials.

The optimal combinations of MVIC tests for the two following acceptance criteria were investigated. Criterion 1 consisted in finding the minimal number of MVIC tests necessary to obtain a muscle activation level $>90 \%$ MVA for at least $90 \%$ of the volunteers (same as in (Dal Maso et al., 2016)). Criterion 2 consisted in the same requirements as criterion 1 plus a defined inter-session reproducibility (variations inferior to $5 \%$ of MVA). The reproducibility (variation between pre- and post-tests results) was based on a Bland and Altman approach. Bland and Altman's approach plot "the individual subject differences between the tests against the respective individual means" (Atkinson and Nevill, 1998). The $90 \%$ limits of agreement were computed. Then, the maximum of the absolute value of the upper and lower bounds of the limits of agreement was kept (a measure of 'total error' (Atkinson and Nevill, 1998)). This approach ensures that, for at least $90 \%$ of the volunteers, an activation level difference $<5 \%$ of MVA between the pre- and post-tests can be expected. The systematic procedure described by Dal Maso et al. (Dal Maso et al., 2016) was then used to identify the optimal combinations. Dal Maso's procedure consists in systematically testing all combinations of MVIC tests. With 12 MVIC tests, a total of 4095 combinations is possible. If several combinations were found that met the criterion, the combination which required the smallest number of tests and then which was valid for the largest number of volunteers was retained. The same procedure was also applied to all muscle combinations which led to a total of more than 1 million tested situations. One should however remain aware that, due to the size of the population and the substantial number of combinations, these supplementary results may be partially biased. 
A combination of 4 normalization tests (4NT) based on Boettcher et al. recommendation (Boettcher et al., 2008) - palm press, empty can, seated $U 125$ and internal rotation $90^{\circ}$ - was taken as a reference. The "internal rotation 90" test from (Boettcher et al., 2008) was however replaced by the "extension prone" test from (Park and Yoo, 2013). Indeed, the "internal rotation $90^{\circ}$ " test was performed to evaluate the MVA of the upper and lower subscapularis muscle, which was not evaluated in the present study as only surface EMG sensors were used.

The elevation of the arm was expressed with respect to the laboratory reference frame. The EMG signals were normalized with the values obtained during the MVIC tests and then expressed relatively to humeral motion and percentage of movement (arm raising: 0 to 100\%; arm lowering: 100 to $0 \%$ ). For each subject, the kinematic and EMG data were average over the five repetitions of the dynamic trial.

\section{Results}

\subsection{Optimal combination of MVIC tests for MVA}

Two single tests (palm press and extension prone) met criterion 1 (for major pectoralis and latissimus dorsi respectively) (Figure 2). Two to four tests were needed to meet criterion 1 for the other individual muscles (Table 2). Additional tests (between one and five) were needed to meet criterion 2 . When criterion 2 was met, all the volunteers achieved a level of muscle activation equal to $100 \%$ of MVA. Nine MVIC normalization tests (9NT: empty can, extension prone, seated $U 90^{\circ}$, palm press, prone $V$-thumb up, rotation $0^{\circ}$, rotation $90^{\circ}$, seated $T$, seated $\mathrm{U} 125^{\circ}$ ) were needed to meet criteria 1 and 2 for all the eight muscles. The combination of MVIC tests needed to meet criterion 1 or 2 for a specific combination of muscles can be found in the supplementary file S1. 


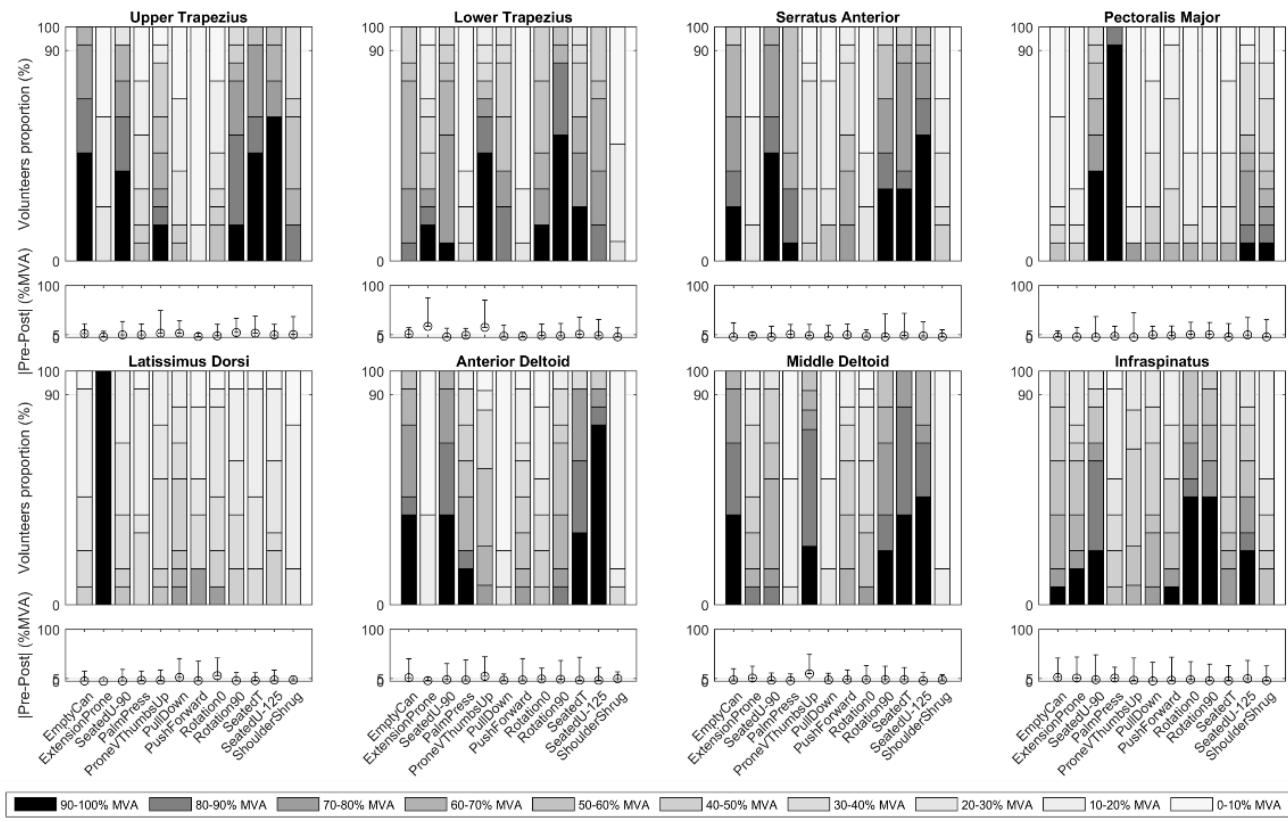

Figure 2: Level of muscles maximal voluntary activation and reproducibility during individual isometric tests. The stacked bars represent the percentage of volunteers within activation level ranges of $10 \%$. The error bars represent the absolute value of the difference (and $90 \%$ confidence interval) of normalized activation between the pre-and post-tests.

Table 2: Combination of MVIC tests meeting criterion 1 (minimum number of MVIC tests for > 90\% MVA for > 90\% volunteers) and criterion 2 (criterion 1 plus a difference of muscle activation < 5\% MVA between pre-and post-tests for 90\% of the volunteers). Size of the window of the moving average filter: $1 \mathrm{~s}$. MVIC: Maximum Voluntary Isometric Contraction. (1) empty can, (2) extension prone, (3) seated $U 90^{\circ},(4)$ palm press, (5) prone $V$-thumb up, (6) pull down, (7) push forward, (8) rotation $0^{\circ},(9)$ rotation 90, (10) seated $T$, (11) seated U $125^{\circ}$, (12) shoulder shrug.

\begin{tabular}{|c|c|c|c|c|c|c|c|c|}
\hline \multirow[b]{2}{*}{ Muscles } & \multicolumn{4}{|c|}{ Criterion 1} & \multicolumn{4}{|c|}{ Criterion 2} \\
\hline & $\begin{array}{l}\text { MVIC } \\
\text { tests }\end{array}$ & $\begin{array}{l}\text { \# of } \\
\text { subjects } \\
(\%)\end{array}$ & $\begin{array}{l}\text { Level of } \\
\text { activation } \\
\text { (\% MVA) }\end{array}$ & $\begin{array}{l}\text { Variation } \\
\text { (\% MVA) }\end{array}$ & $\begin{array}{l}\text { MVIC } \\
\text { tests }\end{array}$ & $\begin{array}{l}\text { \# of } \\
\text { subjects } \\
(\%)\end{array}$ & $\begin{array}{l}\text { Level of } \\
\text { activation } \\
\text { (\% MVA) }\end{array}$ & $\begin{array}{l}\text { Variation } \\
\text { (\% MVA) }\end{array}$ \\
\hline $\begin{array}{l}\text { Upper } \\
\text { Trapezius }\end{array}$ & 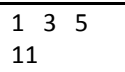 & 92 & 99 & 14.0 & $\begin{array}{lll}1 & 3 & 5 \\
10 & 11\end{array}$ & 100 & 100 & 0.5 \\
\hline $\begin{array}{l}\text { Lower } \\
\text { Trapezius }\end{array}$ & 59 & 92 & 98 & 8.8 & $\begin{array}{l}359 \\
10\end{array}$ & 100 & 100 & 0.9 \\
\hline $\begin{array}{l}\text { Seratus } \\
\text { Anterior }\end{array}$ & 31011 & 100 & 99 & 7.8 & $\begin{array}{lll}3 & 4 & 9 \\
10 & 11\end{array}$ & 100 & 100 & 3.7 \\
\hline $\begin{array}{l}\text { Pectoralis } \\
\text { Major }\end{array}$ & 4 & 92 & 98 & 21.2 & 34 & 100 & 100 & 0.3 \\
\hline $\begin{array}{l}\text { Latissimus } \\
\text { Dorsi }\end{array}$ & 2 & 100 & 100 & 0.0 & 2 & 100 & 100 & 0.0 \\
\hline $\begin{array}{l}\text { Anterior } \\
\text { Deltoid }\end{array}$ & 1011 & 92 & 97 & 15.3 & $\begin{array}{l}3410 \\
11\end{array}$ & 100 & 100 & 4.5 \\
\hline $\begin{array}{l}\text { Middle } \\
\text { Deltoid }\end{array}$ & 11011 & 100 & 99 & 5.7 & $\begin{array}{l}1510 \\
11\end{array}$ & 100 & 100 & 0.0 \\
\hline Infraspinatus & 2389 & 92 & 98 & 12.3 & $\begin{array}{lcc}2 & 3 & 8 \\
9 & 11 & \end{array}$ & 100 & 100 & 1.2 \\
\hline All muscles & $\begin{array}{llll}1 & 2 & 3 & 4 \\
5 & 8 & 9 & \\
10 & 11 & \end{array}$ & 100 & 100 & 1.2 & $\begin{array}{lll}1 & 2 & 3 \\
4 & 5 & 8 \\
9 & 10 & 11\end{array}$ & 100 & 100 & 1.2 \\
\hline
\end{tabular}


Contrary to the 9NT combination, the 4NT combination met only criterion 1 for three of the eight muscles (pectoralis major, latissimus dorsi and anterior deltoid) (Figure 3). For other muscles, between 15\% (lower trapezius) and 77\% (upper trapezius, middle deltoid) of the volunteers achieved $90 \%$ of the MVA. The reproducibility, as defined in this study, was as large as $40 \%$ of MVA (lower trapezius). This means that during the re-test, $10 \%$ of the volunteers had a variation of the muscle level of activity larger than $40 \%$ of MVA when using the 4NT combination.

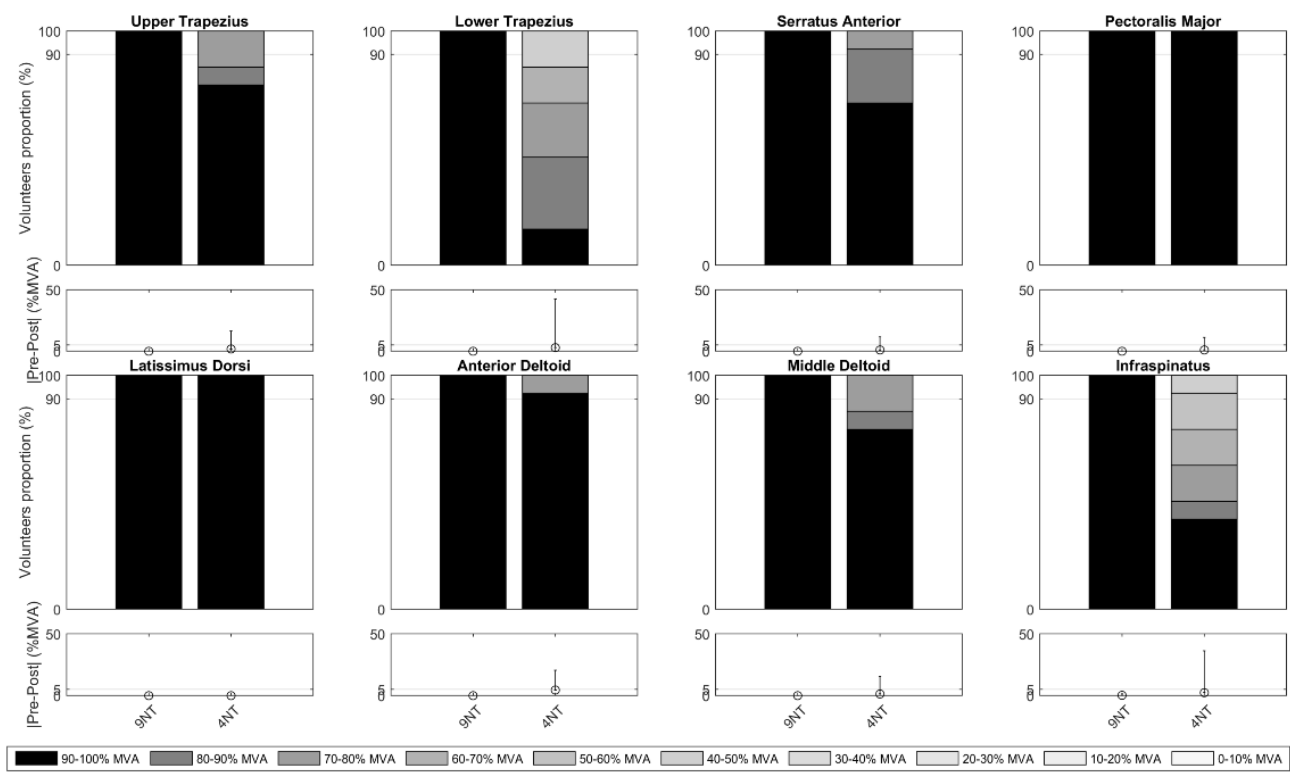

Figure 3: Level of muscles maximal voluntary activation and reproducibility expressed as a fraction of the Maximum Voluntary Activation (MVA) achieved across either 9 tests (9NT: empty can, extension prone, seated $U 90^{\circ}$, palm press, prone $V$-thumb up, rotation $0^{\circ}$, rotation $90^{\circ}$, seated $T$, seated $U 125^{\circ}$ ) or 4 tests (4NT: empty can, extension prone, palm press, seated $U 125^{\circ}$. The stacked bars represent the percentage of volunteers within activation level ranges of $10 \%$. The error bars represent the absolute value of the difference (and 90\% confidence interval) of activation between the pre-and post-tests.

Using either the 9NT combination or all the 12 MVIC tests led to similar muscle levels of activation during the raising and lowering of the arm in the scapular plane (Figure 4). Using only the 4NT combination led to an overestimation of the level of activation for several muscles including the lower trapezius ( $16 \%$ of MVA) and the middle deltoid (5\% of MVA) muscles. 

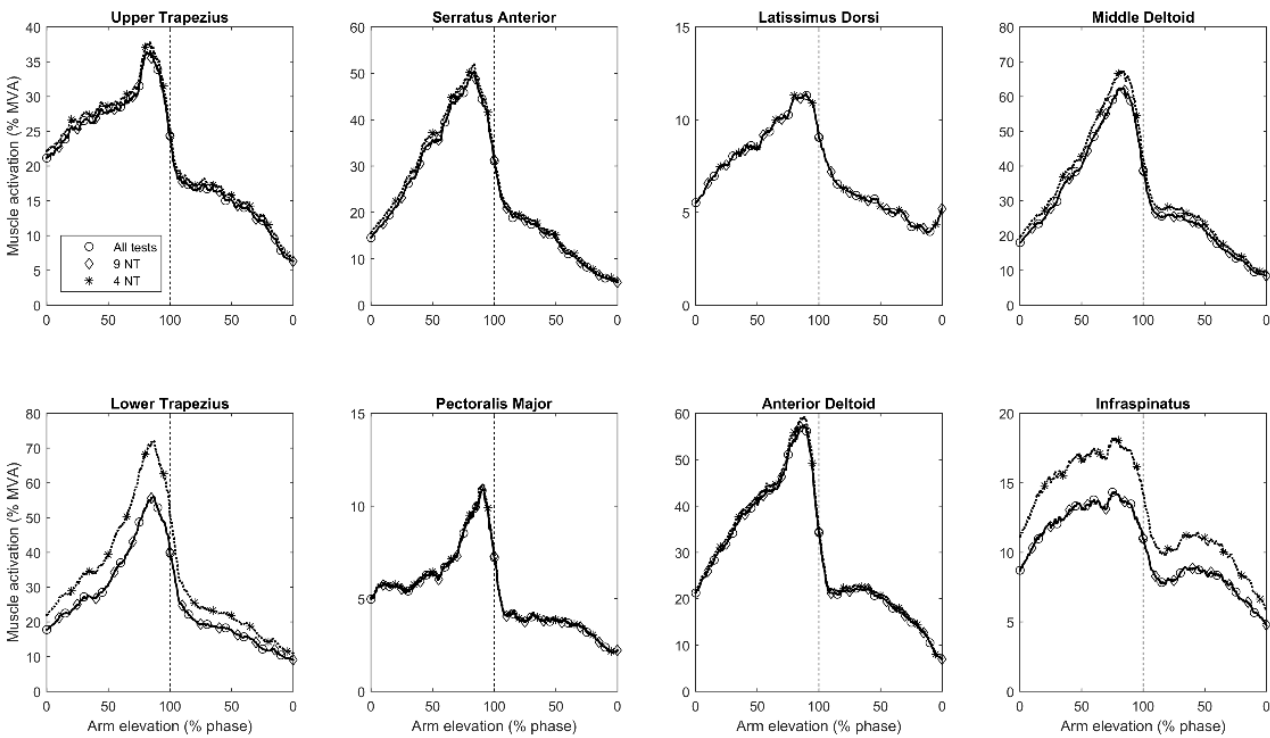

Figure 4: Level of muscle activation when raising and lowering the arm in the scapular plane expressed as a fraction of the Maximum Voluntary Activation (MVA) achieved across either 1/ all tests, $2 / 9$ tests (9NT: empty can, extension prone, seated $U 90^{\circ}$, palm press, prone $V$-thumb up, rotation $0^{\circ}$, rotation $90^{\circ}$, seated $T$, seated $U 125^{\circ}$ ) or $3 / 4$ tests (4NT: empty can, extension prone, palm press, seated $\left.U 125^{\circ}\right)$. The motion is expressed relatively to the percentage of movement (100\% being the maximal elevation).

\subsection{Influence of the moving average filter on the MVA}

When the size of the window used to perform the moving average filter to obtain the MVA was inferior to $1 \mathrm{~s}, 10 \mathrm{MVIC}$ tests (and no longer nine) were needed to meet criteria 2 for all muscles (supplementary file $\mathrm{S} 2$ ).

The size of the window used for the moving average filter to evaluate the MVA had a strong influence on the estimation of the muscle level of activation during arm elevation. Increasing the size of the window increased the estimation of the level of activation of the muscles (Figure 5). For the upper trapezius, the maximal levels of activation were equal to $27 \%$ and $39 \%$ of MVA for the $100 \mathrm{~ms}$ and $2 \mathrm{~s}$ window sizes respectively. For the middle deltoid, the maximal levels of activation were equal to $50 \%$ and $65 \%$ of MVA for the $100 \mathrm{~ms}$ and $2 \mathrm{~s}$ window sizes respectively. 

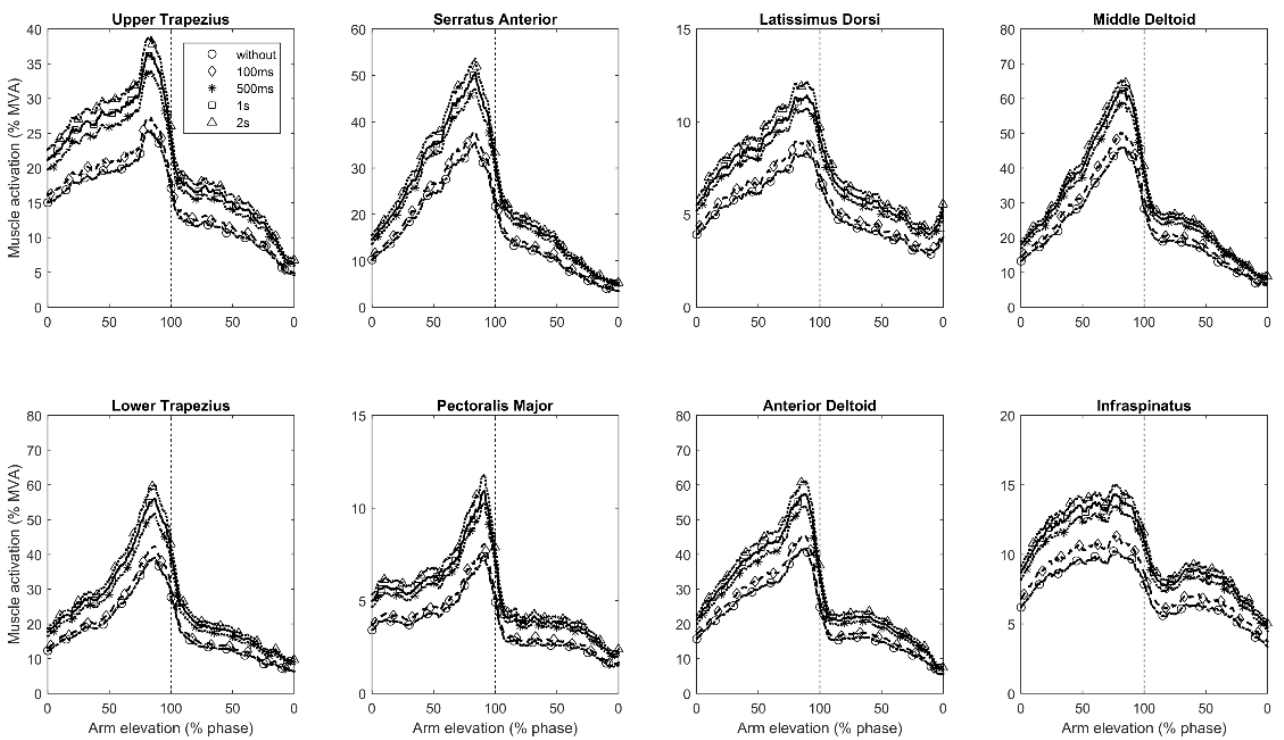

Figure 5: Level of muscle activation when raising and lowering the arm in the scapular plane expressed as a fraction of the Maximum Voluntary Activation (MVA) achieved across all tests. Averaging window size was equal to either: without additional filtering, $100 \mathrm{~ms}, 500 \mathrm{~ms}, 1 \mathrm{~s}$ or 2 s. The motion is expressed relatively to the percentage of movement (100\% being the maximal elevation). The normalization of the muscle activation is performed using all the MVIC tests.

\section{Discussion}

The normalization of the EMG signal is mandatory when comparison between subjects or trials is needed. Previous studies which identified optimal combinations of MVIC tests to obtain the MVA of shoulder muscles did not consider the inter-session reproducibility in the procedure. This contribution is of importance as it will contribute to the definition of modalities able to evaluate the effect, over time, of clinical interventions on the muscle activation patterns. Another aim was to provide a preliminary evaluation of the influence of the EMG signal processing on the MVA estimation and to show that recommendations are needed to improve the possibility to compare studies in the literature.

\subsection{Optimal combination of MVIC tests for MVA}

As stated by Boettcher et al. (Boettcher et al., 2008), the community of EMG users would benefit from a standardization of the protocol used to normalize EMG data. Indeed, results normalized using different protocols may not be comparable. Moreover, the overestimation of the level of activity of a muscle may complexify the clinical interpretation of some results. Our data during an elevation of the arm in the scapular plane demonstrated, for two protocols, that variations of $15 \%$ of MVA can be expected for some muscles. 
Performing MVIC tests is both time consuming and may induce fatigue. There is consequently a large consensus in the literature that an optimal set of MVIC tests containing a limited number of tests should be identified. As underlined in Boettcher's study (Boettcher et al., 2008), we found that single MVIC tests usually activate several muscles. Recording all muscle signals for all the MVIC tests is therefore recommended. Several combinations have been proposed in the literature. Kelly et al. (Kelly et al., 1996), for eight shoulder muscles, and Boettcher et al. (Boettcher et al., 2008), for 13 shoulder muscles, identified combinations of four tests. Castelein et al. (Castelein et al., 2015), for seven shoulder muscles, described a combination of five tests. Ekstrom et al. (Ekstrom et al., 2005) described two to three tests for each of the 4 muscles they studied. Even if some authors (Castelein et al., 2015; Ekstrom et al., 2005) reported the number of volunteers in which the muscle produced MVA, this information was not considered as a primary criterion for the choice of a combination of tests in most studies. Adding this criterion (Dal Maso et al., 2016) led to propositions including two to six MVIC tests per muscle. For all the 12 muscles, 12 MVIC tests were needed to obtain more than $90 \%$ of MVA for more than $90 \%$ of the volunteers. For eight muscles and the same criterion, we found that one to four tests were needed for each muscle and nine tests for all of them (empty can, extension prone, seated $\mathrm{U} 90^{\circ}$, palm press, prone $\mathrm{V}$-thumb up, rotation $0^{\circ}$, rotation $90^{\circ}$, seated $\mathrm{T}$, seated $\cup 125^{\circ}$ ). Our results therefore confirm that four to five tests are probably not enough to obtain a MVA for most of the volunteers.

Boettcher et al. (Boettcher et al., 2008) found that the "internal rotation $90^{\circ}$ " test maximally activate the latissimus dorsi muscle. However, similar results were not obtained in the present study. Similarly, four MVIC tests were found to be necessary in Dal Maso's study (Dal Maso et al., 2016) but none of them were the "internal rotation $90^{\circ}$ " test. The "extension prone" test was found to generate a large activation of the latissimus dorsi muscle (Park and Yoo, 2013) but was not evaluated in Dal Maso's study (Dal Maso et al., 2016). Our results showed that this test alone is sufficient to obtain a MVA of the latissimus dorsi muscle. This test seems therefore a valuable addition to an optimal set of MVIC tests. On the contrary, the "pull down", "push forward" and "shoulder shrug" tests were not used in any combination and should not be favoured.

The reproducibility of the EMG evaluation has been studied in the literature but less has been done concerning the specific reproducibility of the MVA evaluations. Fauth et al. (Fauth et al., 2010) found relatively good inter-session reliability (mean Intra Class Correlation - ICCranging from 0.69 to 0.99 ) for lower limb muscles. Ekstrom et al. (Ekstrom et al., 2005) found a good intra-session reliability (ICC ranging from 0.91 to 0.96 for the recommended MVIC tests). To our knowledge, no specific study has specifically investigated the inter-session reproducibility of the shoulder muscles MVA evaluation. Moreover, a limitation of the ICC statistic is the difficulty to define a clear threshold for what should be an acceptable reproducibility (Atkinson and Nevill, 1998). The approach we chose, based on Bland and Altman plot (Bartlett and Frost, 2008), has the advantage to define a threshold that has a 
clinical meaning: the test re-test difference of the muscle level of activation should not be larger than $5 \%$ of MVA for $90 \%$ of the volunteers. Adding this criterion led to an increase of the number of MVIC tests needed to evaluate individual muscles (one to five MVIC tests). The increase was however limited and the same nine MVIC combination (9NT) was still valid for all the muscles. As the cost to obtain a consistent reproducibility in terms of time is limited, we would recommend to take this variable into account in the future when defining a set of MVIC tests.

Numerous MVIC test positions have been evaluated in the literature (Boettcher et al., 2008; Castelein et al., 2015; Dal Maso et al., 2016; Ekstrom et al., 2005; Park and Yoo, 2013) and all were not tested in the present study. It is therefore conceivable that a better combination of MVIC tests exists. The present study was performed on young male adults and the optimal MVIC combination which is reported here may not be optimal for other populations. Morphological differences, such as the thickness of the adipose tissue in females or older populations, may modify the diffusion of the EMG signal and consequently reduce its amplitude and increase cross talk (Lowery et al., 2001). Moreover, clinical interventions may modify the muscle activation patterns of the patients. One should therefore remain careful when extrapolating the results of reproducibility obtained in this study to other contexts. Eight superficial muscles were evaluated in this study and our conclusions cannot be extended to the other shoulder muscles. Bilateral testing may provide a way to get larger muscle activations (even if the same forces are exerted (Bao et al., 1995)). Indeed, Fischer et al. (Fischer et al., 2011) showed that bilateral exertion tests lead to an increase of the upper trapezius and supraspinatus muscle of approximately $15 \%$. Similar results were obtained by Bao et al. for the upper trapezius (Bao et al., 1995). Furthermore, bilateral testing represents a gain of time when evaluating both the dominant and the non-dominant shoulder.

\subsection{Influence of the moving average filter on the MVA}

Whereas the matter of the choice of the combination of MVIC tests has been raised in the literature, little has been done concerning the influence of the processing of the signal to obtain the MVA value. The usual procedure consists in two steps: 1 / the EMG signal is processed similarly as during the dynamic (or static) evaluations (i.e. RMS extraction of the EMG linear envelope); this step was not studied in the present study but some indications can be found in (Fischer et al., 2010) 2/ the MVA may then be directly extracted from the envelope (peak value) (Burden, 2010) or defined as the mean peak of the signal further filtered using a moving average filter. The cutoff frequency of the filter is related to the window size (or time constant (Merletti and Torino, 2015)). Window sizes ranging from 2 to $3 \mathrm{~s}$ are commonly used in the literature (Castelein et al., 2015; Dal Maso et al., 2016; Ekstrom et al., 2005). In the present study, we used window sizes ranging from $100 \mathrm{~ms}$ (limited smoothing) to $2 \mathrm{~s}$ (large smoothing). The obtained results demonstrate that the choice of the size of the window can have a significant impact on the interpretation of the level of activation of the muscles as the level of activation can be multiplied by 1.5 between $100 \mathrm{~ms}$ and $2 \mathrm{~s}$. These results show that 
comparison of EMG values between studies may not be always possible. Similar results were obtained for the deltoid muscle and different window sizes (Fischer et al., 2010). For the RMS approach, they found variations of $10 \%$ between the peak extraction methods. The effect of the size of the window is homogeneous among all the muscles, which was not the case concerning the choice of the combination of MVIC tests chosen for normalization. Along with the choice of the MVIC tests, physiological and anatomical factors (Halaki and Ginn, 2012), verbal encouragements and feedbacks (Fischer et al., 2010), the filtering choices may therefore also explain why some studies report activations level larger than $100 \%$ of MVA (Selkowitz et al., 2007).

It should however be noted that reduced filtering led to an increase of the MVIC tests needed to meet the criterion acceptance limits. For inter-session repeatability, our results showed that with window sizes smaller than $1 \mathrm{~s}$, additional MVIC tests are needed. Fischer et al. (Fischer et al., 2010) identified that a 500 ms window size improves intra-session repeatability in comparison with a simple peak value extraction method. Based on Fischer's results (Fischer et al., 2010) on intra-session repeatability and ours on inter-session repeatability, a peak extraction technique based on moving average window with a window size comprises between $500 \mathrm{~ms}$ and $1 \mathrm{~s}$ seems reasonable. One should however remain aware that, when interpreting the normalized EMG signal, that the level of activation of the muscles will be overestimated. The influence of the post-processing on the evaluation of the MVA as reported in this study should be seen as preliminary. Indeed, other parameters such as the size of the RMS window, the number of trials considered, using a consecutive or non-consecutive (Dal Maso et al., 2016) window for moving average filtering should be further investigated before identifying a standardized procedure. The results of this study, however, emphasize the influence of this signal processing step on the final interpretation of the results and the possibility to compare studies.

\section{Conclusion}

Our results show that more than four or five MVIC tests are needed to obtain a reproducible MVA for all the studied shoulder muscles. A combination of nine MVIC tests was found to maximally activate eight shoulder muscles. One major output of this study is that the same combination of nine MVIC tests also provides a good inter-session reproducibility. For individual muscles, the reproducibility criterion imposes a few additional MVIC tests in comparison with previous recommendations. Our study also demonstrates that the process used to extract the MVA from the EMG envelope has a large effect on the estimation of the level of activation of the shoulder muscles during a dynamic gesture. These results emphasize the need to standardize the EMG signal normalization procedure. 


\section{Acknowledgements}

The authors wish to thank the Wallonia-Brussels Federation for its support. The authors also thank M. Soulier for his help in data collection. 


\section{References}

Atkinson, G., Nevill, A., 1998. Statistical Methods for Assessing Measurement Error (Reliability) in Variables Relevant to Sports Medicine. Sport. Med. 26, 217-238. doi:10.2165/00007256-199826040-00002

Bao, S., Mathiassen, S.E., Winkel, J., 1995. Normalizing upper trapezius EMG amplitude: Comparison of different procedures. J. Electromyogr. Kinesiol. 5, 251-257. doi:10.1016/1050-6411(95)00005-4

Barbero, M., Merletti, R., Rainoldi, A., 2012. Atlas of Muscle Innervation Zones. Springer Milan. doi:10.1007/978-88-470-2463-2

Bartlett, J.W., Frost, C., 2008. Reliability, repeatability and reproducibility: Analysis of measurement errors in continuous variables. Ultrasound Obstet. Gynecol. 31, 466-475. doi:10.1002/uog.5256

Boettcher, C.E., Ginn, K.A., Cathers, I., 2008. Standard maximum isometric voluntary contraction tests for normalizing shoulder muscle EMG. J. Orthop. Res. 26, 1591-1597. doi:10.1002/jor.20675

Burden, A., 2010. How should we normalize electromyograms obtained from healthy participants? What we have learned from over 25 years of research. J. Electromyogr. Kinesiol. 20, 1023-1035. doi:10.1016/j.jelekin.2010.07.004

Castelein, B., Cagnie, B., Parlevliet, T., Danneels, L., Cools, A., 2015. Optimal Normalization Tests for Muscle Activation of the Levator Scapulae, Pectoralis Minor, and Rhomboid Major: An Electromyography Study Using Maximum Voluntary Isometric Contractions. Arch. Phys. Med. Rehabil. 96, 1820-1827. doi:10.1016/j.apmr.2015.06.004

Dal Maso, F., Marion, P., Begon, M., 2016. Optimal Combinations of Isometric Normalization Tests for the Production of Maximum Voluntary Activation of the Shoulder Muscles. Arch. Phys. Med. Rehabil. 97, 1542-1551. doi:10.1016/j.apmr.2015.12.024

De Luca, C.J., 1993. The use of surface electromyography in biomechanics. J. Appl. Biomech. 13, 135-163.

Ekstrom, R.A., Soderberg, G.L., Donatelli, R.A., 2005. Normalization procedures using maximum voluntary isometric contractions for the serratus anterior and trapezius muscles during surface EMG analysis. J. Electromyogr. Kinesiol. 15, 418-428. doi:10.1016/j.jelekin.2004.09.006

Fauth, M.L., Petushek, E.J., Feldmann, C.R., Hsu, B.E., Garceau, L.R., Lutsch, B.N., Ebben, W.P., 2010. Reliability of surface electromyography during maximal voluntary isometric contractions, jump landings, and cutting. J. Strength Cond. Res. 24, 1131-1137. doi:10.1519/JSC.0b013e3181cc2353

Fischer, S.L., Belbeck, A.L., Dickerson, C.R., 2010. The influence of providing feedback on force production and within-participant reproducibility during maximal voluntary exertions for the anterior deltoid, middle deltoid, and infraspinatus. J. Electromyogr. Kinesiol. 20, 6875. doi:10.1016/j.jelekin.2009.01.007

Fischer, S.L., Grewal, T.J., Wells, R., Dickerson, C.R., 2011. Effect of bilateral versus unilateral 
exertion tests on maximum voluntary activity and within-participant reproducibility in the shoulder. J. Electromyogr. Kinesiol. 21, 311-317. doi:10.1016/j.jelekin.2010.05.002

Halaki, M., Ginn, K. a, 2012. Normalization of EMG Signals: To Normalize or Not to Normalize and What to Normalize to?, in: Naik, G.R. (Ed.), Computational Intelligence in Electromyography Analysis - A Perspective on Current Applications and Future Challenges. InTech, pp. 175-194. doi:10.5772/49957

Kelly, B.T., Kadrmas, W.R., Kirkendall, D.T., Speer, K.P., 1996. Optimal Normalization Tests for Shoulder Muscle Activation: An Electromyographic Study. J. of Orthopedic Res. 14, 647653. doi:10.1002/jor.1100140421

Lowery, M., Stoykov, N., Taflove, A., Kuiken, T., 2001. A multi-layer finite element model of the surface EMG signal 2, 1051-1054 vol.2. doi:10.1109/IEMBS.2001.1020369

Mathiassen, S.E., Winkel, J., Hägg, G.M., 1995. Normalization of surface EMG amplitude from the upper trapezius muscle in ergonomic studies-a review. J. Electromyogr. Kinesiol. 5, 197-226.

Merletti, A.R., Torino, P., 2015. Standards for Reporting EMG Data. J. Electromyogr. Kinesiol. 25, I-II. doi:10.1016/S1050-6411(15)00221-7

Park, S. yeon, Yoo, W. gyu, 2013. Comparison of exercises inducing maximum voluntary isometric contraction for the latissimus dorsi using surface electromyography. J. Electromyogr. Kinesiol. 23, 1106-1110. doi:10.1016/j.jelekin.2013.05.003

Schwartz, C., Denoël, V., Forthomme, B., Croisier, J.-L.J.-L., Brüls, O., 2015. Merging multicamera data to reduce motion analysis instrumental errors using Kalman filters. Comput. Methods Biomech. Biomed. Engin. 18, 952-960. doi:10.1080/10255842.2013.864640

Selkowitz, D.M., Chaney, C., Stuckey, S.J., Vlad, G., 2007. The effects of scapular taping on the surface electromyographic signal amplitude of shoulder girdle muscles during upper extremity elevation in individuals with suspected shoulder impingement syndrome. J. Orthop. Sports Phys. Ther. 37, 694-702. doi:10.2519/jospt.2007.2467 
Supplementary file S1: For all combination of muscles, combination of MVIC tests meeting criterion 1 (minimum number of MVIC tests for $>90 \%$ MVA for $>90 \%$ volunteers) and criterion 2 (criterion 1 plus a difference of muscle activation $<5 \%$ MVA between pre-and post-tests for $90 \%$ of the volunteers). Size of the window of the moving average filter: 1 s. MVIC: Maximum Voluntary Isometric Contraction. (1) empty can, (2) extension prone, (3) seated $U 90^{\circ}$, (4) palm press, (5) prone $V$-thumb up, (6) pull down, (7) push forward, (8) rotation $0^{\circ}$, (9) rotation 90, (10) seated $T$, (11) seated $U 125^{\circ},(12)$ shoulder shrug.

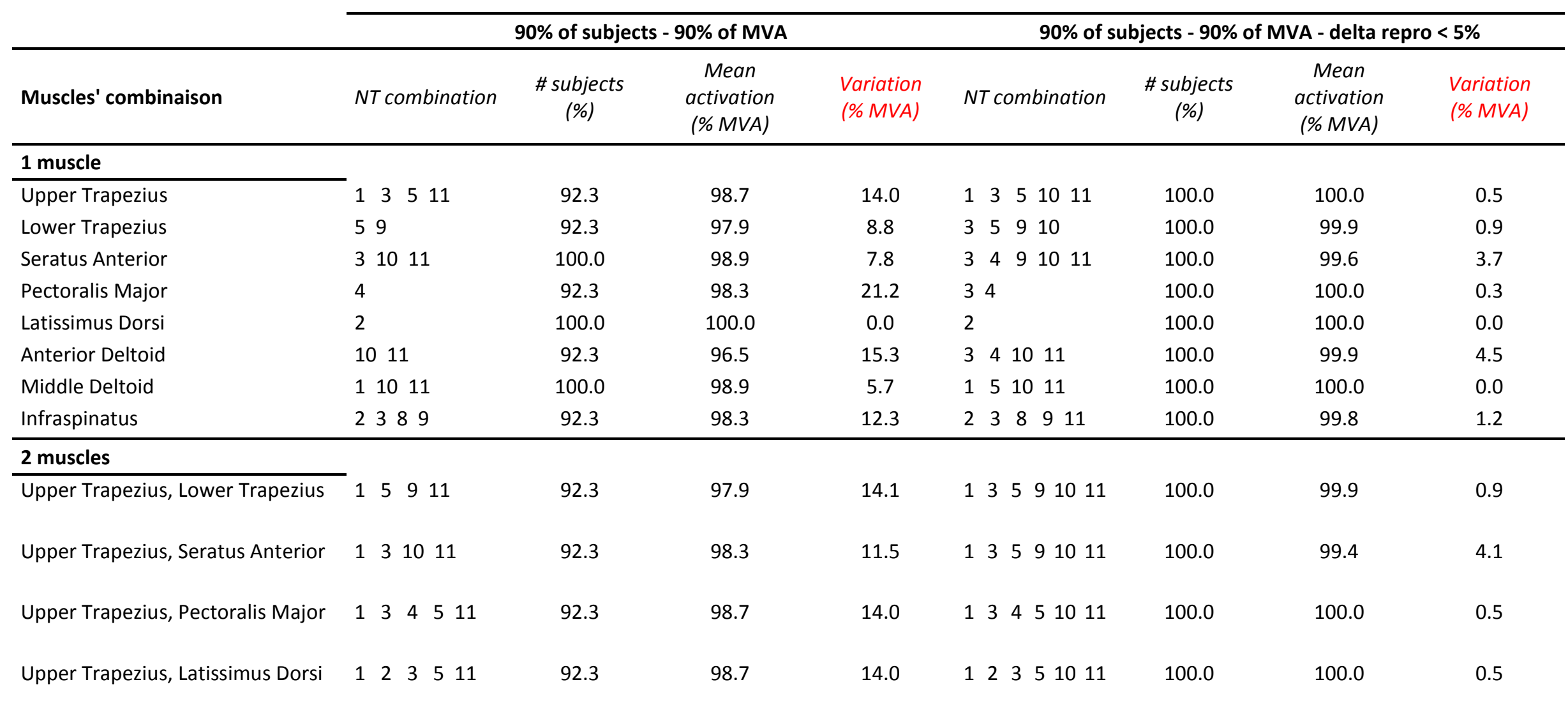




\begin{tabular}{|c|c|c|c|c|c|c|c|c|}
\hline Upper Trapezius, Anterior Deltoid & 13511 & 92.3 & 98.7 & 18.7 & 13451011 & 100.0 & 100.0 & 0.5 \\
\hline Upper Trapezius, Middle Deltoid & 131011 & 92.3 & 98.3 & 11.5 & $\begin{array}{lllll}1 & 3 & 5 & 10 & 11\end{array}$ & 100.0 & 100.0 & 0.5 \\
\hline Upper Trapezius, Infraspinatus & $\begin{array}{llllll}1 & 3 & 5 & 8 & 9 & 11\end{array}$ & 92.3 & 97.0 & 17.2 & $\begin{array}{llllll}1 & 2 & 3 & 5 & 8 & 9 \\
10 & 11 & & & \end{array}$ & 100.0 & 99.8 & 1.2 \\
\hline Lower Trapezius, Seratus Anterior & 359910 & 92.3 & 95.8 & 25.4 & $\begin{array}{llllll}3 & 4 & 9 & 10 & 11\end{array}$ & 100.0 & 99.6 & 3.7 \\
\hline Lower Trapezius, Pectoralis Major & 459 & 92.3 & 97.9 & 21.2 & $\begin{array}{lllll}3 & 4 & 5 & 9 & 10\end{array}$ & 100.0 & 99.9 & 0.9 \\
\hline Lower Trapezius, Latissimus Dorsi & 259 & 92.3 & 97.9 & 8.8 & $\begin{array}{lllll}2 & 3 & 5 & 9 & 10\end{array}$ & 100.0 & 99.9 & 0.2 \\
\hline Lower Trapezius, Anterior Deltoid & $\begin{array}{llll}5 & 9 & 10 & 11\end{array}$ & 92.3 & 96.5 & 15.3 & $\begin{array}{llllll}3 & 4 & 5 & 10 & 11\end{array}$ & 100.0 & 99.9 & 4.5 \\
\hline Lower Trapezius, Middle Deltoid & $\begin{array}{lllll}1 & 5 & 9 & 10 & 11\end{array}$ & 92.3 & 99.0 & 5.8 & 13591011 & 100.0 & 99.9 & 0.9 \\
\hline Lower Trapezius, Infraspinatus & 23589 & 92.3 & 98.3 & 12.3 & $\begin{array}{llllll}2 & 3 & 5 & 8 & 9 & 10 \\
11 & & & & & \end{array}$ & 100.0 & 99.8 & 1.2 \\
\hline Seratus Anterior, Pectoralis Major & 41011 & 92.3 & 98.7 & 13.8 & $\begin{array}{lllll}3 & 4 & 9 & 10 & 11\end{array}$ & 100.0 & 99.6 & 3.7 \\
\hline Seratus Anterior, Latissimus Dorsi & 231011 & 100.0 & 98.9 & 7.8 & 23491011 & 100.0 & 99.6 & 3.7 \\
\hline Seratus Anterior, Anterior Deltoid & 31011 & 92.3 & 98.5 & 9.8 & $\begin{array}{lllll}3 & 4 & 9 & 10 & 11\end{array}$ & 100.0 & 99.6 & 4.5 \\
\hline Seratus Anterior, Middle Deltoid & 131011 & 100.0 & 98.9 & 6.7 & 13591011 & 100.0 & 99.4 & 4.1 \\
\hline Seratus Anterior, Infraspinatus & $\begin{array}{lllll}3 & 8 & 9 & 10 & 11\end{array}$ & 92.3 & 97.0 & 17.2 & $\begin{array}{llllll}2 & 3 & 4 & 8 & 9 & 10 \\
11 & & & & & \end{array}$ & 100.0 & 99.6 & 3.7 \\
\hline Pectoralis Major, Latissimus Dorsi & 24 & 92.3 & 98.3 & 21.2 & 234 & 100.0 & 100.0 & 0.3 \\
\hline Pectoralis Major, Anterior Deltoid & 41011 & 100.0 & 97.9 & 14.4 & $\begin{array}{llll}3 & 4 & 10 & 11\end{array}$ & 100.0 & 99.9 & 4.5 \\
\hline Pectoralis Major, Middle Deltoid & 141011 & 100.0 & 98.9 & 11.2 & 13451011 & 100.0 & 100.0 & 0.0 \\
\hline Pectoralis Major, Infraspinatus & 23489 & 92.3 & 98.3 & 12.3 & $\begin{array}{llllll}2 & 3 & 4 & 8 & 9 & 11\end{array}$ & 100.0 & 99.8 & 1.2 \\
\hline Latissimus Dorsi, Anterior Deltoid & 21011 & 92.3 & 96.5 & 15.3 & 2341011 & 100.0 & 99.9 & 4.5 \\
\hline Latissimus Dorsi, Middle Deltoid & 121011 & 100.0 & 98.9 & 5.7 & 1251011 & 100.0 & 100.0 & 0.0 \\
\hline Latissimus Dorsi, Infraspinatus & 2389 & 92.3 & 98.3 & 12.3 & $\begin{array}{lllll}2 & 3 & 8 & 9 & 11\end{array}$ & 100.0 & 99.8 & 1.2 \\
\hline
\end{tabular}




\begin{tabular}{|c|c|c|c|c|c|c|c|c|c|c|}
\hline Anterior Deltoid, Middle Deltoid & 110 & 011 & & 92.3 & 96.7 & 15.9 & $\begin{array}{llllll}1 & 3 & 4 & 5 & 10 & 11\end{array}$ & 100.0 & 100.0 & 0.0 \\
\hline Anterior Deltoid, Infraspinatus & 13 & 38 & 911 & 92.3 & 97.0 & 18.7 & $\begin{array}{llllll}2 & 3 & 4 & 8 & 9 & 10 \\
11 & & & & & \end{array}$ & 100.0 & 99.8 & 4.5 \\
\hline Middle Deltoid, Infraspinatus & $\begin{array}{l}13 \\
11\end{array}$ & 38 & 8910 & 92.3 & 97.0 & 17.2 & $\begin{array}{llllll}1 & 2 & 3 & 5 & 8 & 9 \\
10 & 11 & & & \end{array}$ & 100.0 & 99.8 & 1.2 \\
\hline \multicolumn{11}{|l|}{3 muscles } \\
\hline $\begin{array}{l}\text { Upper Trapezius, Lower Trapezius, } \\
\text { Seratus Anterior }\end{array}$ & 35 & 59 & 1011 & 92.3 & 97.2 & 14.3 & 135591011 & 100.0 & 99.4 & 4.1 \\
\hline $\begin{array}{l}\text { Upper Trapezius, Lower Trapezius, } \\
\text { Pectoralis Major }\end{array}$ & 14 & 45 & 911 & 92.3 & 97.9 & 14.1 & $\begin{array}{llllll}1 & 3 & 4 & 5 & 9 & 10 \\
11 & & & & & \end{array}$ & 100.0 & 99.9 & 0.9 \\
\hline $\begin{array}{l}\text { Upper Trapezius, Lower Trapezius, } \\
\text { Latissimus Dorsi }\end{array}$ & 12 & 25 & 911 & 92.3 & 97.9 & 14.1 & $\begin{array}{llllll}1 & 2 & 3 & 5 & 9 & 10 \\
11 & & & & & \end{array}$ & 100.0 & 99.9 & 0.2 \\
\hline $\begin{array}{l}\text { Upper Trapezius, Lower Trapezius, } \\
\text { Anterior Deltoid }\end{array}$ & 59 & 910 & 011 & 92.3 & 96.5 & 15.3 & $\begin{array}{llllll}1 & 3 & 4 & 5 & 9 & 10 \\
11 & & & & & \end{array}$ & 100.0 & 99.9 & 0.9 \\
\hline $\begin{array}{l}\text { Upper Trapezius, Lower Trapezius, } \\
\text { Middle Deltoid }\end{array}$ & 15 & 59 & 1011 & 92.3 & 99.0 & 5.8 & $\begin{array}{lllll}13 & 5 & 9 & 10\end{array}$ & 100.0 & 99.9 & 0.9 \\
\hline $\begin{array}{l}\text { Upper Trapezius, Lower Trapezius, } \\
\text { Infraspinatus }\end{array}$ & 13 & 35 & 8911 & 92.3 & 97.0 & 17.2 & $\begin{array}{llllll}1 & 2 & 3 & 5 & 8 & 9 \\
10 & 11 & & & \end{array}$ & 100.0 & 99.8 & 1.2 \\
\hline $\begin{array}{l}\text { Upper Trapezius, Seratus Anterior, } \\
\text { Pectoralis Major }\end{array}$ & 13 & 34 & 1011 & 92.3 & 98.3 & 11.5 & $\begin{array}{llllll}1 & 3 & 4 & 5 & 9 & 10 \\
11 & & & & \end{array}$ & 100.0 & 100.0 & 0.0 \\
\hline $\begin{array}{l}\text { Upper Trapezius, Seratus Anterior, } \\
\text { Latissimus Dorsi }\end{array}$ & 12 & 23 & 1011 & 92.3 & 98.3 & 11.5 & $\begin{array}{llllll}1 & 2 & 3 & 5 & 9 & 10 \\
11 & & & & \end{array}$ & 100.0 & 99.4 & 4.1 \\
\hline $\begin{array}{l}\text { Upper Trapezius, Seratus Anterior, } \\
\text { Anterior Deltoid }\end{array}$ & 13 & 310 & 011 & 92.3 & 98.3 & 11.5 & $\begin{array}{llllll}1 & 3 & 4 & 5 & 9 & 10 \\
11 & & & & & \end{array}$ & 100.0 & 100.0 & 0.0 \\
\hline $\begin{array}{l}\text { Upper Trapezius, Seratus Anterior, } \\
\text { Middle Deltoid }\end{array}$ & 13 & 310 & 011 & 92.3 & 98.3 & 11.5 & $\begin{array}{llllll}1 & 3 & 5 & 1011\end{array}$ & 100.0 & 99.4 & 4.1 \\
\hline $\begin{array}{l}\text { Upper Trapezius, Seratus Anterior, } \\
\text { Infraspinatus }\end{array}$ & $\begin{array}{l}13 \\
11\end{array}$ & $3 \varepsilon$ & $\begin{array}{lll}8 & 9 & 10\end{array}$ & 92.3 & 97.0 & 17.2 & $\begin{array}{llllll}1 & 2 & 3 & 5 & 8 & 9 \\
10 & 11 & & & \end{array}$ & 100.0 & 99.4 & 4.1 \\
\hline $\begin{array}{l}\text { Upper Trapezius, Pectoralis Major, } \\
\text { Latissimus Dorsi }\end{array}$ & 12 & 23 & 4511 & 92.3 & 98.7 & 14.0 & $\begin{array}{llllll}1 & 2 & 3 & 4 & 5 & 10 \\
11 & & & & & \end{array}$ & 100.0 & 100.0 & 0.5 \\
\hline
\end{tabular}


Upper Trapezius, Pectoralis Major, $113 \quad 4 \quad 5 \quad 511$ Anterior Deltoid

Upper Trapezius, Pectoralis Major, 13441011 Middle Deltoid

Upper Trapezius, Pectoralis Major, $\begin{array}{lllllll}1 & 3 & 4 & 5 & 8 & 9\end{array}$ Infraspinatus

$$
11
$$

Upper Trapezius, Latissimus Dorsi, $1 \begin{array}{lllll}1 & 2 & 3 & 5 & 11\end{array}$

Anterior Deltoid

Upper Trapezius, Latissimus Dorsi, 1231011 Middle Deltoid

Upper Trapezius, Latissimus Dorsi, $1 \begin{array}{llllll}1 & 2 & 3 & 5 & 8 & 9\end{array}$

11

Infraspinatus

Upper Trapezius, Anterior Deltoid, 131011 Middle Deltoid

Upper Trapezius, Anterior Deltoid, $\begin{array}{llllll}1 & 3 & 5 & 8 & 9 & 11\end{array}$ Infraspinatus

Upper Trapezius, Middle Deltoid, $\begin{array}{llllll}1 & 3 & 8 & 9 & 10\end{array}$

Infraspinatus

11

Lower Trapezius, Seratus Anterior, $4 \quad 5 \quad 9 \quad 1011$ Pectoralis Major

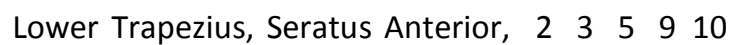

Latissimus Dorsi

Lower Trapezius, Seratus Anterior, 3591011 Anterior Deltoid

Lower Trapezius, Seratus Anterior, $\begin{array}{lllll}1 & 3 & 5 & 9 & 10\end{array}$

Middle Deltoid

11

Lower Trapezius, Seratus Anterior, $\begin{array}{llllll}3 & 5 & 8 & 9 & 10\end{array}$ Infraspinatus 11

Lower Trapezius, Pectoralis Major, 2459

Latissimus Dorsi

Lower Trapezius, Pectoralis Major, $\begin{aligned} & 3 \quad 4 \quad 5 \quad 911\end{aligned}$

Anterior Deltoid

\begin{tabular}{|c|c|c|c|c|c|}
\hline 92.3 & 98.7 & 16.7 & 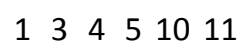 & 100.0 & 100.0 \\
\hline 92.3 & 98.3 & 11.5 & 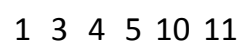 & 100.0 & 100.0 \\
\hline 92.3 & 97.0 & 17.2 & $\begin{array}{cccccc}1 & 2 & 3 & 4 & 5 & 8 \\
9 & 10 & 11 & & \end{array}$ & 100.0 & 99.8 \\
\hline 92.3 & 98.7 & 18.7 & $\begin{array}{llllll}1 & 2 & 3 & 4 & 5 & 10 \\
11 & & & & \end{array}$ & 100.0 & 100.0 \\
\hline 92.3 & 98.3 & 11.5 & 12351011 & 100.0 & 100.0 \\
\hline 92.3 & 98.7 & 13.5 & $\begin{array}{llllll}1 & 2 & 3 & 5 & 8 & 9 \\
10 & 11 & & & \end{array}$ & 100.0 & 99.8 \\
\hline 92.3 & 98.3 & 11.5 & 13451011 & 100.0 & 100.0 \\
\hline 92.3 & 97.0 & 18.7 & $\begin{array}{cccccc}1 & 2 & 3 & 4 & 5 & 8 \\
9 & 10 & 11 & & & \end{array}$ & 100.0 & 99.8 \\
\hline 92.3 & 97.0 & 17.2 & $\begin{array}{llllll}1 & 2 & 3 & 5 & 8 & 9 \\
10 & 11 & & & \end{array}$ & 100.0 & 99.8 \\
\hline 92.3 & 98.8 & 12.0 & $\begin{array}{llllll}3 & 4 & 5 & 9 & 10\end{array}$ & 100.0 & 99.6 \\
\hline 92.3 & 95.8 & 25.4 & $\begin{array}{llllll}2 & 3 & 4 & 5 & 9 & 10 \\
11 & & & & \end{array}$ & 100.0 & 99.6 \\
\hline 92.3 & 98.5 & 9.8 & $\begin{array}{lllll}3 & 4 & 5 & 1011\end{array}$ & 100.0 & 99.6 \\
\hline 100.0 & 99.4 & 4.1 & 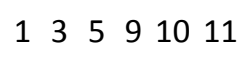 & 100.0 & 99.4 \\
\hline 92.3 & 97.0 & 17.2 & $\begin{array}{llllll}2 & 3 & 4 & 5 & 8 & 9 \\
10 & 11 & & & \end{array}$ & 100.0 & 99.6 \\
\hline 92.3 & 97.9 & 21.2 & 2345910 & 100.0 & 99.9 \\
\hline 92.3 & 98.0 & 23.7 & $\begin{array}{llllll}3 & 4 & 5 & 9 & 10 & 11\end{array}$ & 100.0 & 99.9 \\
\hline
\end{tabular}



Middle Deltoid

Lower Trapezius, Pectoralis Major, 234589

Infraspinatus

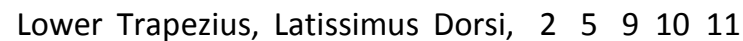
Anterior Deltoid

$\begin{array}{llllll}\text { Lower Trapezius, Latissimus Dorsi, } & 1 & 2 & 5 & 9 & 10\end{array}$ Middle Deltoid 11

Lower Trapezius, Latissimus Dorsi, 23589 Infraspinatus

Lower Trapezius, Anterior Deltoid, $1 \quad 5 \quad 91011$ Middle Deltoid

Lower Trapezius, Anterior Deltoid, $\begin{array}{llllll}1 & 3 & 5 & 8 & 9 & 11\end{array}$ Infraspinatus

Lower Trapezius, Middle Deltoid, $\begin{array}{llllll}1 & 3 & 5 & 8 & 9 & 10\end{array}$ Infraspinatus

Seratus Anterior, Pectoralis Major, 241011

Latissimus Dorsi

Seratus Anterior, Pectoralis Major, 41011

Anterior Deltoid

Seratus Anterior, Pectoralis Major, 141011

Middle Deltoid

Seratus Anterior, Pectoralis Major, $\begin{array}{lllll}3 & 4 & 8 & 9 & 10\end{array}$

Infraspinatus

11

Seratus Anterior, Latissimus Dorsi, 231011

Anterior Deltoid

Seratus Anterior, Latissimus Dorsi, $1 \quad 2 \quad 3 \quad 1011$

Middle Deltoid

Seratus Anterior, Latissimus Dorsi, $\begin{array}{llllll}2 & 3 & 8 & 9 & 10\end{array}$

Infraspinatus

Seratus Anterior, Anterior Deltoid, 131011

Middle Deltoid

97.9

98.9

97.0

98.5

98.9

95.8

98.7
11.2

12.3

15.3

5.8

12.3

15.9

18.7

17.2

13.8

9.1 $\begin{array}{lllllll}1 & 3 & 4 & 5 & 9 & 10 & 100.0\end{array}$

99.9

99.8

99.9

$\begin{array}{llllll}2 & 3 & 4 & 5 & 9\end{array}$

100.0

100.0

99.9

100.0

99.8

100.0

99.9

100.0

$\begin{array}{llllll}2 & 3 & 4 & 5 & 8 & 9\end{array}$ 1011

$\begin{array}{llllll}1 & 2 & 3 & 5 & 8\end{array}$

100.0

1011

$2 \begin{array}{llllll}2 & 4 & 9 & 10\end{array}$

100.0

100.0

$\begin{array}{lllll}3 & 4 & 9 & 10 & 11\end{array}$

100.0

$\begin{array}{llllll}1 & 3 & 4 & 5 & 9 & 10\end{array}$

100.0

100.0

$\begin{array}{llllll}2 & 3 & 4 & 8 & 9 & 10\end{array}$

$$
11
$$

$2 \begin{array}{lllll}2 & 4 & 9 & 1011\end{array}$

100.0

100.0

12235910

100.0

$\begin{array}{llllll}2 & 3 & 4 & 8 & 9 & 10\end{array}$

11

100.0 
Seratus Anterior, Anterior Deltoid, $3 \quad 8 \quad 91011$ Infraspinatus

Seratus Anterior, Middle Deltoid, $\begin{array}{llllll}1 & 3 & 8 & 9 & 10\end{array}$ Infraspinatus 11

Pectoralis Major, Latissimus Dorsi, 241011 Anterior Deltoid

Pectoralis Major, Latissimus Dorsi, 12241011 Middle Deltoid

Pectoralis Major, Latissimus Dorsi, 23489 Infraspinatus

Pectoralis Major, Anterior Deltoid, 141011 Middle Deltoid

Pectoralis Major, Anterior Deltoid, $\begin{array}{llllll}3 & 4 & 8 & 9 & 11\end{array}$ Infraspinatus

Pectoralis Major, Middle Deltoid, $\begin{array}{llllll}1 & 3 & 4 & 8 & 9 & 10\end{array}$ Infraspinatus$$
11
$$

Latissimus Dorsi, Anterior Deltoid, 121011

Middle Deltoid

Latissimus Dorsi, Anterior Deltoid, $\begin{array}{llllll}1 & 2 & 3 & 8 & 9 & 11\end{array}$

Latissimus Dorsi, Middle Deltoid, $\begin{array}{lllllll}1 & 2 & 3 & 8 & 9 & 10\end{array}$ 11

Anterior Deltoid, Middle Deltoid, $\begin{array}{llllll}1 & 3 & 8 & 9 & 10\end{array}$ Infraspinatus Infraspinatus Infraspinatus

\section{3}

92.3

100.0

100.0

92.3

100.0

92.3

92.3

92.3

100.0

92.3

\section{4 muscles}

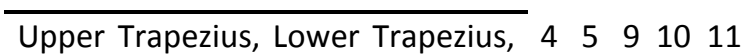
Seratus Anterior, Pectoralis Major

$\begin{array}{llllll}\text { Upper Trapezius, Lower Trapezius, } & 2 & 3 & 5 & 9 & 10\end{array}$ Seratus Anterior, Latissimus Dorsi 11

Upper Trapezius, Lower Trapezius, $3 \quad 591011$ Seratus Anterior, Anterior Deltoid $\begin{array}{lllllll}1 & 2 & 3 & 5 & 8 & 9 & 100.0\end{array}$

99.4

1011

100.0

100.0

100.0
1
100.0

99.9 

Seratus Anterior, Middle Deltoid 11

Upper Trapezius, Lower Trapezius, $3 \begin{array}{lllll}3 & 5 & 8 & 9 & 10\end{array}$

Seratus Anterior, Infraspinatus 11

Upper Trapezius, Lower Trapezius, $1 \begin{array}{llllll}1 & 2 & 4 & 5 & 9 & 11\end{array}$ Pectoralis Major, Latissimus Dorsi

Upper Trapezius, Lower Trapezius, 1445911

Pectoralis Major, Anterior Deltoid

Upper Trapezius, Lower Trapezius, $1 \begin{array}{lllll}1 & 4 & 5 & 9 & 10\end{array}$

Pectoralis Major, Middle Deltoid 11

Upper Trapezius, Lower Trapezius, $1 \begin{array}{llllll}1 & 3 & 4 & 5 & 8 & 9\end{array}$

Pectoralis Major, Infraspinatus

$$
11
$$

Upper Trapezius, Lower Trapezius, 2591011

Latissimus Dorsi, Anterior Deltoid

Upper Trapezius, Lower Trapezius, $1 \quad \begin{array}{lllll}2 & 5 & 9 & 10\end{array}$

Latissimus Dorsi, Middle Deltoid 11

$\begin{array}{lllllll}\text { Upper Trapezius, Lower Trapezius, } & 1 & 2 & 3 & 5 & 8 & 9\end{array}$

Latissimus Dorsi, Infraspinatus

11

Upper Trapezius, Lower Trapezius, $1 \quad 5 \quad 91011$ Anterior Deltoid, Middle Deltoid

Upper Trapezius, Lower Trapezius, 1 \begin{tabular}{llllll}
\hline & 5 & 8 & 9 & 11
\end{tabular}

Anterior Deltoid, Infraspinatus

Upper Trapezius, Lower Trapezius, $\begin{array}{llllll}1 & 3 & 5 & 8 & 9 & 10\end{array}$ Middle Deltoid, Infraspinatus

Upper Trapezius, Seratus Anterior, $1 \begin{array}{lllll}1 & 2 & 3 & 4 & 10\end{array}$

Pectoralis Major, Latissimus Dorsi 11

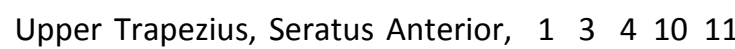

Pectoralis Major, Anterior Deltoid

Upper Trapezius, Seratus Anterior, 13341011

Pectoralis Major, Middle Deltoid
100.0
4.1

17.2

14.1

20.5

11.2

17.2

15.3

99.0

98.7

96.7

97.0

98.3

98.3

11.5
13591011

100.0

99.4

99.4

99.9

99.9

99.9

99.8

99.9

99.9

99.8

99.9

99.8

99.8

100.0

100.0

$\begin{array}{lll}1 & 2 & 3 \\ 10 & 11\end{array}$

$\begin{array}{llllll}1 & 3 & 4 & 5 & 9 & 10\end{array}$

100.0

100.0

100.0

100.0
4.1

4.1

0.9

0.9

0.2

1.2

0.0

0.0 
Pectoralis Major, Infraspinatus

11

Upper Trapezius, Seratus Anterior, $1 \begin{array}{lllll}2 & 2 & 3 & 10 & 11\end{array}$

Latissimus Dorsi, Anterior Deltoid

Upper Trapezius, Seratus Anterior, 112231011

Latissimus Dorsi, Middle Deltoid

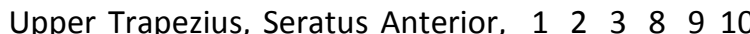

Latissimus Dorsi, Infraspinatus

Upper Trapezius, Seratus Anterior, 131011

Anterior Deltoid, Middle Deltoid

Upper Trapezius, Seratus Anterior, $1 \begin{array}{lllll}1 & 3 & 8 & 9 & 10\end{array}$

Anterior Deltoid, Infraspinatus

11

Upper Trapezius, Seratus Anterior, $1 \begin{array}{lllll}1 & 3 & 8 & 9 & 10\end{array}$

Middle Deltoid, Infraspinatus

11

Upper Trapezius, Pectoralis Major, $\begin{array}{lllllll}1 & 2 & 3 & 4 & 5 & 11\end{array}$

Latissimus Dorsi, Anterior Deltoid

Upper Trapezius, Pectoralis Major, $1 \begin{array}{lllll}1 & 2 & 3 & 4 & 10\end{array}$

Latissimus Dorsi, Middle Deltoid 11

Upper Trapezius, Pectoralis Major, $\begin{array}{llllll}1 & 2 & 3 & 4 & 5 & 8\end{array}$

Latissimus Dorsi, Infraspinatus

911

Upper Trapezius, Pectoralis Major, $1 \quad 3 \quad 4 \quad 1011$

Anterior Deltoid, Middle Deltoid

Upper Trapezius, Pectoralis Major, $1 \begin{array}{llllll}1 & 3 & 4 & 5 & 8 & 9\end{array}$

Anterior Deltoid, Infraspinatus 11

Upper Trapezius, Pectoralis Major, $1 \begin{array}{llllll}3 & 4 & 8 & 9 & 10\end{array}$

Middle Deltoid, Infraspinatus

11

Upper Trapezius, Latissimus Dorsi, $1 \begin{array}{lllll}1 & 2 & 3 & 10 & 11\end{array}$

Anterior Deltoid, Middle Deltoid

Upper Trapezius, Latissimus Dorsi, $1 \begin{array}{llllll}1 & 2 & 3 & 5 & 8 & 9\end{array}$

Anterior Deltoid, Infraspinatus
17.2

11.5

11.5

11.5

11.5

17.2

17.2

16.7

11.5

13.5

11.5

17.2

17.2

11.5

18.7 $\begin{array}{lllllll}1 & 2 & 3 & 4 & 5 & 8 & 100.0\end{array}$

91011

$\begin{array}{lllllll}1 & 2 & 3 & 4 & 5 & 9 & 100.0\end{array}$

1011

$\begin{array}{llllll}1 & 2 & 3 & 5 & 9 & 10\end{array}$

11

$\begin{array}{llllll}1 & 2 & 3 & 5 & 8\end{array}$

1011

$\begin{array}{llllll}1 & 3 & 4 & 5 & 9 & 10\end{array}$

11

$\begin{array}{lllllll}1 & 2 & 3 & 4 & 5 & 8 & 100.0\end{array}$

91011

$\begin{array}{lllllll}1 & 2 & 3 & 5 & 8 & 9 & 100.0\end{array}$

1011

12234510

11

$\begin{array}{llllll}1 & 2 & 3 & 4 & 5 & 10\end{array}$

11

$\begin{array}{lllllll}1 & 2 & 3 & 4 & 5 & 8 & 100.0\end{array}$

91011

13455101

$\begin{array}{llllll}1 & 2 & 3 & 4 & 5 & 8\end{array}$

91011

$\begin{array}{llllll}1 & 2 & 3 & 4 & 5 & 8\end{array}$

91011

$\begin{array}{llllll}1 & 2 & 3 & 4 & 5 & 10\end{array}$

11

91011 

Middle Deltoid, Infraspinatus

Upper Trapezius, Anterior Deltoid, $1 \begin{array}{lllll}1 & 3 & 8 & 9 & 10\end{array}$ Middle Deltoid, Infraspinatus

11

Lower Trapezius, Seratus Anterior, $\begin{array}{llllll}2 & 4 & 5 & 9 & 10\end{array}$

Pectoralis Major, Latissimus Dorsi 11

Lower Trapezius, Seratus Anterior, 45991011

Pectoralis Major, Anterior Deltoid

Lower Trapezius, Seratus Anterior, $1 \begin{array}{lllll}1 & 4 & 5 & 9 & 10\end{array}$

Pectoralis Major, Middle Deltoid 11

Lower Trapezius, Seratus Anterior, $\begin{array}{llllll}3 & 4 & 5 & 8 & 9 & 10\end{array}$

Pectoralis Major, Infraspinatus

Lower Trapezius, Seratus Anterior, $\begin{array}{llllll}2 & 3 & 5 & 9 & 10\end{array}$

Latissimus Dorsi, Anterior Deltoid 11

Lower Trapezius, Seratus Anterior, $\begin{array}{llllll}1 & 2 & 3 & 5 & 9 & 10\end{array}$

Latissimus Dorsi, Middle Deltoid 11

Lower Trapezius, Seratus Anterior, $\begin{array}{lllllll}2 & 3 & 5 & 8 & 9 & 10\end{array}$ Latissimus Dorsi, Infraspinatus

Lower Trapezius, Seratus Anterior, $\begin{array}{lllll}1 & 3 & 5 & 9 & 10\end{array}$ Anterior Deltoid, Middle Deltoid 11

Lower Trapezius, Seratus Anterior, $\begin{array}{lllll}3 & 5 & 8 & 9 & 10\end{array}$

Anterior Deltoid, Infraspinatus 11

Lower Trapezius, Seratus Anterior, $1 \begin{array}{llllll}3 & 5 & 8 & 9 & 10\end{array}$ Middle Deltoid, Infraspinatus

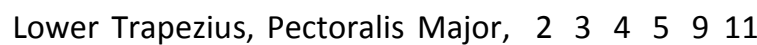
Latissimus Dorsi, Anterior Deltoid

Lower Trapezius, Pectoralis Major, $\begin{array}{llllll}1 & 2 & 4 & 5 & 9 & 10\end{array}$ Latissimus Dorsi, Middle Deltoid 11

Lower Trapezius, Pectoralis Major, 234589 Latissimus Dorsi, Infraspinatus

$$
11
$$



Anterior Deltoid, Middle Deltoid 11

Lower Trapezius, Pectoralis Major, $\begin{array}{llllll}3 & 4 & 5 & 8 & 9 & 11\end{array}$ Anterior Deltoid, Infraspinatus

Lower Trapezius, Pectoralis Major, $\begin{array}{llllll}1 & 3 & 4 & 5 & 8 & 9\end{array}$ Middle Deltoid, Infraspinatus$$
1011
$$

Lower Trapezius, Latissimus Dorsi, $\begin{array}{llllll}1 & 2 & 5 & 9 & 10\end{array}$ Anterior Deltoid, Middle Deltoid 11

Lower Trapezius, Latissimus Dorsi, $\begin{array}{lllllll}1 & 2 & 3 & 5 & 8 & 9\end{array}$ Anterior Deltoid, Infraspinatus$$
11
$$

Lower Trapezius, Latissimus Dorsi, $\begin{array}{lllllll}1 & 2 & 3 & 5 & 8 & 9\end{array}$ Middle Deltoid, Infraspinatus$$
1011
$$

Lower Trapezius, Anterior Deltoid, $1 \begin{array}{llllll}1 & 5 & 8 & 9 & 10\end{array}$

Middle Deltoid, Infraspinatus 11

Seratus Anterior, Pectoralis Major, 241011 Latissimus Dorsi, Anterior Deltoid

Seratus Anterior, Pectoralis Major, $1 \quad 2 \quad 4 \quad 41011$ Latissimus Dorsi, Middle Deltoid

Seratus Anterior, Pectoralis Major, $\begin{array}{llllll}2 & 3 & 4 & 8 & 9 & 10\end{array}$ Latissimus Dorsi, Infraspinatus

Seratus Anterior, Pectoralis Major, 141011

Anterior Deltoid, Middle Deltoid

Seratus Anterior, Pectoralis Major, $\begin{array}{llllll}3 & 4 & 8 & 9 & 10\end{array}$ Anterior Deltoid, Infraspinatus

\section{1}

Seratus Anterior, Pectoralis Major, $1 \begin{array}{llllll}3 & 4 & 8 & 9 & 10\end{array}$ Middle Deltoid, Infraspinatus 11

Seratus Anterior, Latissimus Dorsi, $1 \begin{array}{lllll}2 & 3 & 10 & 11\end{array}$ Anterior Deltoid, Middle Deltoid

Seratus Anterior, Latissimus Dorsi, $\begin{array}{llllll}2 & 3 & 8 & 9 & 10\end{array}$ Anterior Deltoid, Infraspinatus $\begin{array}{llllll}1 & 2 & 3 & 4 & 5 & 8\end{array}$

100.0

1011

$\begin{array}{llllll}1 & 2 & 3 & 5 & 8 & 9\end{array}$

100.0 
Seratus Anterior, Latissimus Dorsi, $\begin{array}{llllll}1 & 2 & 3 & 8 & 9 & 10\end{array}$

Middle Deltoid, Infraspinatus

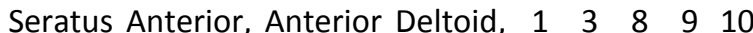

Middle Deltoid, Infraspinatus

11

Pectoralis Major, Latissimus Dorsi, 112241011

Anterior Deltoid, Middle Deltoid

Pectoralis Major, Latissimus Dorsi, $\begin{array}{lllllll}2 & 3 & 4 & 8 & 9 & 11\end{array}$

Anterior Deltoid, Infraspinatus

Pectoralis Major, Latissimus Dorsi, $1 \begin{array}{lllllll}1 & 2 & 3 & 4 & 8 & 9 & 100.0\end{array}$

Middle Deltoid, Infraspinatus

1011

Pectoralis Major, Anterior Deltoid, $1 \begin{array}{llllll}1 & 3 & 4 & 8 & 9 & 10\end{array}$ Middle Deltoid, Infraspinatus 11

Latissimus Dorsi, Anterior Deltoid, $\begin{array}{llllll}1 & 2 & 3 & 8 & 9 & 10\end{array}$

\section{5 muscles}

$\begin{array}{llllll}\text { Upper Trapezius, Lower Trapezius, } & 2 & 4 & 5 & 9 & 10\end{array}$

Seratus Anterior, Pectoralis Major, 11

Latissimus Dorsi

Upper Trapezius, Lower Trapezius, 45991011 Seratus Anterior, Pectoralis Major,

Anterior Deltoid

Upper Trapezius, Lower Trapezius, $\begin{array}{lllll}1 & 4 & 5 & 9 & 10\end{array}$

Seratus Anterior, Pectoralis Major,

\section{Middle Deltoid}

Upper Trapezius, Lower Trapezius, 344589910

Seratus Anterior, Pectoralis Major, 11

Infraspinatus

Upper Trapezius, Lower Trapezius, $2 \begin{array}{lllll}2 & 3 & 5 & 9 & 10\end{array}$

Seratus Anterior, Latissimus Dorsi, 11

Anterior Deltoid $\begin{array}{llllll}1 & 2 & 3 & 4 & 5 & 8\end{array}$

100.0

$\begin{array}{llllll}1 & 2 & 3 & 4 & 5 & 9\end{array}$

100.0

99.9

$$
1011
$$

133455910

100.0

99.9

0.9

11

11.2

$\begin{array}{llllll}1 & 3 & 4 & 5 & 9 & 10\end{array}$

100.0

99.9

0.9

11

100.0

99.8

$$
91011
$$

99.9

0.2 $\begin{array}{lllllll}1 & 2 & 3 & 4 & 5 & 9 & 100.0\end{array}$

1011 
Upper Trapezius, Lower Trapezius, $\begin{array}{llllll}1 & 2 & 3 & 5 & 9 & 10\end{array}$

\section{Middle Deltoid}

Upper Trapezius, Lower Trapezius, $\begin{array}{llllll}2 & 3 & 5 & 8 & 9 & 10\end{array}$

Infraspinatus

Upper Trapezius, Lower Trapezius, $1 \begin{array}{lllll}1 & 3 & 5 & 9 & 10\end{array}$

Seratus Anterior, Anterior Deltoid, 11

Middle Deltoid

Upper Trapezius, Lower Trapezius, $\begin{array}{llllll}3 & 5 & 8 & 9 & 10\end{array}$

Seratus Anterior, Anterior Deltoid, 11

Infraspinatus

Upper Trapezius, Lower Trapezius, $1 \begin{array}{llllll}1 & 3 & 5 & 8 & 9 & 10\end{array}$

Seratus Anterior, Middle Deltoid, 11

Infraspinatus

Upper Trapezius, Lower Trapezius, $1 \begin{array}{llllll}2 & 4 & 5 & 9 & 11\end{array}$

Pectoralis Major, Latissimus Dorsi,

Anterior Deltoid

Upper Trapezius, Lower Trapezius, 1124455910

Pectoralis Major, Latissimus Dorsi, 11

Middle Deltoid

Upper Trapezius, Lower Trapezius, $1 \begin{array}{llllll}1 & 2 & 3 & 4 & 5 & 8\end{array}$

Pectoralis Major, Latissimus Dorsi, 911

Infraspinatus

Upper Trapezius, Lower Trapezius, $1 \begin{array}{lllll}1 & 4 & 5 & 9 & 10\end{array}$

Pectoralis Major, Anterior Deltoid, 11

Middle Deltoid

Upper Trapezius, Lower Trapezius, $1 \begin{array}{llllll}1 & 3 & 4 & 5 & 8 & 9\end{array}$

Pectoralis Major, Anterior Deltoid, 11

Infraspinatus

97.0
4.1

1223559910

100.0

$\begin{array}{llllll}12 & 3 & 5 & 8 & 9\end{array}$

100.0

99.4

9.1

$\begin{array}{llllll}1 & 3 & 4 & 5 & 9 & 10\end{array}$

100.0

99.9

0.9

11

$\begin{array}{llllllll}1 & 2 & 3 & 4 & 5 & 8 & 100.0 & 99.8\end{array}$

91011

17.2

$\begin{array}{llllll}1 & 2 & 3 & 5 & 8 & 9\end{array}$

$$
1011
$$

$$
1011
$$

100.0

99.4 
Upper Trapezius, Lower Trapezius, $\begin{array}{llllll}1 & 3 & 4 & 5 & 8 & 9\end{array}$

Pectoralis Major, Middle Deltoid, 1011

97.0

Infraspinatus

Upper Trapezius, Lower Trapezius, $1 \begin{array}{lllll}1 & 2 & 5 & 9 & 10\end{array}$

Latissimus Dorsi, Anterior Deltoid, 11

Middle Deltoid

Upper Trapezius, Lower Trapezius, $1 \begin{array}{llllll}1 & 2 & 3 & 5 & 8 & 9\end{array}$

Infraspinatus

Upper Trapezius, Lower Trapezius, $1 \begin{array}{llllll} & 2 & 3 & 5 & 8 & 9\end{array}$

Latissimus Dorsi, Middle Deltoid, 1011

Infraspinatus

Upper Trapezius, Lower Trapezius, $1 \begin{array}{llllll}1 & 3 & 8 & 9 & 10\end{array}$

Anterior Deltoid, Middle Deltoid, 11

Infraspinatus

Upper Trapezius, Seratus Anterior, $1 \begin{array}{lllll}1 & 2 & 3 & 4 & 10\end{array}$

Pectoralis Major, Latissimus Dorsi, 11

Anterior Deltoid

Upper Trapezius, Seratus Anterior, $\begin{array}{llllll}1 & 2 & 3 & 4 & 10\end{array}$

Pectoralis Major, Latissimus Dorsi, 11

Middle Deltoid

Upper Trapezius, Seratus Anterior, $\begin{array}{lllllll}1 & 2 & 3 & 4 & 8 & 9\end{array}$

nfraspinatus

Upper Trapezius, Seratus Anterior, 13341011

Pectoralis Major, Anterior Deltoid

Middle Deltoid

Upper Trapezius, Seratus Anterior, $1 \begin{array}{llllll}1 & 3 & 4 & 8 & 9 & 10\end{array}$

Pectoralis Major, Anterior Deltoid, 11

Infraspinatus

97.0

97.0
17.2

$\begin{array}{llllll}1 & 2 & 3 & 4 & 5 & 8\end{array}$

100.0

99.8

1.2

$\begin{array}{llllll}1 & 2 & 3 & 4 & 5 & 9\end{array}$

100.0

99.9

1011

18.7

$\begin{array}{llllll}1 & 2 & 3 & 4 & 5 & 8\end{array}$

100.0

99.8

91011

$\begin{array}{llll}2 & 3 & 5 & 8\end{array}$

100.0

99.8

$$
1011
$$

17.2

$\begin{array}{llllll}1 & 2 & 3 & 4 & 5 & 8\end{array}$

100.0

99.8

91011

11.5

$\begin{array}{llllll}1 & 2 & 3 & 4 & 5 & 9\end{array}$

100.0

100.0

1011

11.5

$\begin{array}{llllll}1 & 2 & 3 & 4 & 5 & 9\end{array}$

100.0

100.0

1011

11.5

$\begin{array}{llllll}1 & 2 & 3 & 4 & 5 & 8\end{array}$

100.0

99.8

91011

11.5

$\begin{array}{llllll}1 & 3 & 4 & 5 & 9 & 10\end{array}$

100.0

100.0

0.0

$$
11
$$

17.2

$\begin{array}{llllll}1 & 2 & 3 & 4 & 5 & 8\end{array}$

100.0

99.8 
Upper Trapezius, Seratus Anterior, $\begin{array}{llllll}1 & 3 & 4 & 8 & 9 & 10\end{array}$

Pectoralis Major, Middle Deltoid, 11

\section{Infraspinatus}

Upper Trapezius, Seratus Anterior, $122 \quad 3 \quad 1011$

Middle Deltoid

Upper Trapezius, Seratus Anterior, $\begin{array}{lllllll}1 & 2 & 3 & 8 & 9 & 10\end{array}$

Latissimus Dorsi, Anterior Deltoid, 11

Infraspinatus

Upper Trapezius, Seratus Anterior, $\begin{array}{llllll}1 & 2 & 3 & 8 & 9 & 10\end{array}$

Latissimus Dorsi, Middle Deltoid, 11

Infraspinatus

Upper Trapezius, Seratus Anterior, $1 \begin{array}{lllll}1 & 3 & 8 & 9 & 10\end{array}$

Anterior Deltoid, Middle Deltoid, 11

Infraspinatus

Upper Trapezius, Pectoralis Major, $1 \begin{array}{lllll}1 & 2 & 3 & 4 & 10\end{array}$

tissimus Dorsi, Anterior Deltoid, 11

Middle Deltoid

Upper Trapezius, Pectoralis Major, $\begin{array}{llllll}1 & 2 & 3 & 4 & 5 & 8\end{array}$

Latissimus Dorsi, Anterior Deltoid, 911

Infraspinatus

Upper Trapezius, Pectoralis Major, $1 \begin{array}{llllll}1 & 2 & 3 & 4 & 8 & 9\end{array}$

nfraspinatus

Upper Trapezius, Pectoralis Major, $\begin{array}{llllll}1 & 3 & 4 & 8 & 9 & 10\end{array}$

Anterior Deltoid, Middle Deltoid, 11

Infraspinatus

Upper Trapezius, Latissimus Dorsi, $1 \begin{array}{llllll}1 & 2 & 3 & 8 & 9 & 10\end{array}$

Anterior Deltoid, Middle Deltoid, 11

Infraspinatus

97.0

98.3 $\begin{array}{lllllllll}17.2 & 1 & 2 & 3 & 4 & 5 & 8 & 100.0 & 99.8\end{array}$

1234559

100.0

100.0

0.0

1011

11.5

$\begin{array}{llllll}1 & 2 & 3 & 4 & 5 & 8\end{array}$

100.0

99.8

91011

11.5

$\begin{array}{llllll}1 & 2 & 3 & 5 & 8 & 9\end{array}$

100.0

99.4

$$
1011
$$

17.2

$\begin{array}{llllll}1 & 2 & 3 & 4 & 5 & 8\end{array}$

100.0

99.8

91011

11.5

$\begin{array}{llllll}1 & 2 & 3 & 4 & 5 & 10\end{array}$

100.0

100.0

0.5

16.7

$\begin{array}{llllll}1 & 2 & 3 & 4 & 5 & 8\end{array}$

100.0

99.8

11.5

$\begin{array}{llllll}1 & 2 & 3 & 4 & 5 & 8\end{array}$

100.0

99.8

91011

$\begin{array}{llllll}1 & 2 & 3 & 4 & 5 & 8\end{array}$

100.0

99.8

91011

11.5

$\begin{array}{llllll}1 & 2 & 3 & 4 & 5 & 8\end{array}$

100.0

99.8

1.2 
Lower Trapezius, Seratus Anterior, $\begin{array}{lllll}2 & 4 & 5 & 9 & 10\end{array}$ Pectoralis Major, Latissimus Dorsi, 11

Anterior Deltoid

Lower Trapezius, Seratus Anterior, $1 \begin{array}{llllll}1 & 2 & 4 & 5 & 9 & 10\end{array}$

Pectoralis Major, Latissimus Dorsi, 11

Middle Deltoid

Lower Trapezius, Seratus Anterior, $2 \begin{array}{llllll}2 & 3 & 4 & 5 & 8 & 9\end{array}$

Pectoralis Major, Latissimus Dorsi, 10

Infraspinatus

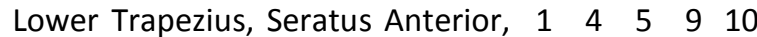

Pectoralis Major, Anterior Deltoid, 11

Middle Deltoid

Lower Trapezius, Seratus Anterior, $\begin{array}{llllll}3 & 4 & 5 & 8 & 9 & 10\end{array}$

Pectoralis Major, Anterior Deltoid, 11

Infraspinatus

Lower Trapezius, Seratus Anterior, $1 \begin{array}{llllll}1 & 3 & 4 & 5 & 8 & 9\end{array}$

Pectoralis Major, Middle Deltoid, 1011

Infraspinatus

Lower Trapezius, Seratus Anterior, $\begin{array}{llllll}1 & 2 & 3 & 5 & 9 & 10\end{array}$

Latissimus Dorsi, Anterior Deltoid, 11

Middle Deltoid

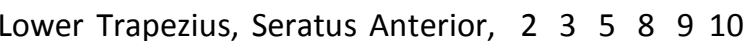

(a)issimus Dorsi, Anterior Deltoid, 11

nfraspinatus

Lower Trapezius, Seratus Anterior, $\begin{array}{lllllll}1 & 2 & 3 & 5 & 8 & 9\end{array}$

100.0

Latissimus Dorsi, Middle Deltoid, 1011

Infraspinatus

Lower Trapezius, Seratus Anterior, $\begin{array}{llllll}1 & 3 & 5 & 8 & 9 & 10\end{array}$

Anterior Deltoid, Middle Deltoid, 11

Infraspinatus

97.0

97.0 $\begin{array}{llllll}12 & 3 & 4 & 5 & 9\end{array}$

100.0

99.9

1011

$\begin{array}{llllll}2 & 3 & 4 & 5 & 8 & 9\end{array}$

100.0

99.6

1011

99.9

11

17.2

100.0

$\begin{array}{llllll}1 & 2 & 3 & 4 & 5 & 9\end{array}$

100.0

99.9

1011

9.8

$\begin{array}{lllll}2 & 3 & 4 & 5 & 8\end{array}$

100.0

99.6

1011

4.1

$\begin{array}{llllll}1 & 2 & 3 & 5 & 8 & 9\end{array}$

100.0

99.4 
Lower Trapezius, Pectoralis Major, $\begin{array}{llllll}1 & 2 & 4 & 5 & 9 & 10\end{array}$

Latissimus Dorsi, Anterior Deltoid, 11

\section{Middle Deltoid}

Lower Trapezius, Pectoralis Major, $\begin{array}{llllll}2 & 3 & 4 & 5 & 8 & 9\end{array}$

Infraspinatus

Lower Trapezius, Pectoralis Major, $\begin{array}{llllll}1 & 2 & 3 & 4 & 5 & 8\end{array}$

100.0

Latissimus Dorsi, Middle Deltoid, 91011

Infraspinatus

Lower Trapezius, Pectoralis Major, $1 \begin{array}{llllll}1 & 3 & 4 & 5 & 8 & 9\end{array}$

Anterior Deltoid, Middle Deltoid, 1011

Infraspinatus

Lower Trapezius, Latissimus Dorsi, $1 \begin{array}{llllll}1 & 2 & 3 & 5 & 8 & 9\end{array}$

Anterior Deltoid, Middle Deltoid, 1011

Infraspinatus

Seratus Anterior, Pectoralis Major, 11241011

tissimus Dorsi, Anterior Deltoid,

Middle Deltoid

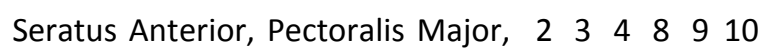

Latissimus Dorsi, Anterior Deltoid, 11

Infraspinatus

Seratus Anterior, Pectoralis Major, $\begin{array}{lllllll}1 & 2 & 3 & 4 & 8 & 9\end{array}$

Latissimus Dorsi, Middle Deltoid, 1011

Infraspinatus

Seratus Anterior, Pectoralis Major, $\begin{array}{llllll}1 & 3 & 4 & 8 & 9 & 10\end{array}$

Anterior Deltoid, Middle Deltoid, 11

Infraspinatus

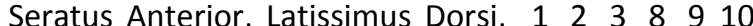

Anterior Deltoid, Middle Deltoid, 11

Infraspinatus

98.7

98.0

98.7
14.2

$\begin{array}{llllll}1 & 2 & 3 & 4 & 5 & 9\end{array}$

100.0

99.9

0.2

1011

23.7

$\begin{array}{llllll}2 & 3 & 4 & 5 & 8 & 9\end{array}$

100.0

99.8

4.5

1011

$\begin{array}{llllllll}1.2 & 1 & 2 & 3 & 4 & 5 & 8 & 1000\end{array}$

99.8

1.2

$9 \begin{array}{lll}9 & 10 & 11\end{array}$

17.2

$\begin{array}{llllll}1 & 2 & 3 & 4 & 5 & 8\end{array}$

100.0

99.8

91011

$\begin{array}{lll}1 & 2 & 3 \\ 9 & 10 & 11\end{array}$

100.0

99.8

1.2

14.2

$\begin{array}{llllll}1 & 2 & 3 & 4 & 5 & 9\end{array}$

100.0

100.0

0.0

1011

$\begin{array}{lllllll}4.5 & 2 & 3 & 4 & 8 & 9 & 10\end{array}$

100.0

99.6

4.5

11

$\begin{array}{llllllll}5.2 & 1 & 2 & 3 & 4 & 5 & 8 & 1000\end{array}$

99.8

91011

17.2

$\begin{array}{llllll}1 & 2 & 3 & 4 & 5 & 8\end{array}$

100.0

99.8

1.2 $\begin{array}{lll}9 & 10 & 11\end{array}$

$\begin{array}{llllllll}9.1 & 1 & 2 & 3 & 4 & 5 & 8 & 100.0\end{array}$

91011 
Pectoralis Major, Latissimus Dorsi, $1 \begin{array}{lllllll}1 & 2 & 3 & 4 & 8 & 9 & 100.0\end{array}$

99.0

5.2

$\begin{array}{llllll}1 & 2 & 3 & 4 & 5 & 8\end{array}$

100.0

Infraspinatus

\begin{tabular}{|c|c|c|c|}
\hline 6 muscles & & & \\
\hline $\begin{array}{l}\text { Upper Trapezius, Lower Trapezius, } \\
\text { Seratus Anterior, Pectoralis Major, } \\
\text { Latissimus Dorsi, Anterior Deltoid }\end{array}$ & $\begin{array}{ll}2 & 4 \\
11\end{array}$ & 5 & 910 \\
\hline $\begin{array}{l}\text { Upper Trapezius, Lower Trapezius, } \\
\text { Seratus Anterior, Pectoralis Major, } \\
\text { Latissimus Dorsi, Middle Deltoid }\end{array}$ & $\begin{array}{ll}12 & 24 \\
11 & \end{array}$ & 5 & 910 \\
\hline $\begin{array}{l}\text { Upper Trapezius, Lower Trapezius, } \\
\text { Seratus Anterior, Pectoralis Major, } \\
\text { Latissimus Dorsi, Infraspinatus }\end{array}$ & $\begin{array}{lll}2 & 3 & 4 \\
10 & 11\end{array}$ & 45 & 89 \\
\hline $\begin{array}{l}\text { Upper Trapezius, Lower Trapezius, } \\
\text { Seratus Anterior, Pectoralis Major, } \\
\text { Anterior Deltoid, Middle Deltoid }\end{array}$ & $\begin{array}{l}14 \\
11\end{array}$ & 5 & 910 \\
\hline $\begin{array}{l}\text { Upper Trapezius, Lower Trapezius, } \\
\text { Seratus Anterior, Pectoralis Major, } \\
\text { Anterior Deltoid, Infraspinatus }\end{array}$ & $\begin{array}{l}345 \\
11\end{array}$ & 8 & 910 \\
\hline $\begin{array}{l}\text { Upper Trapezius, Lower Trapezius, } \\
\text { Seratus Anterior, Pectoralis Major, } \\
\text { Middle Deltoid, Infraspinatus }\end{array}$ & $\begin{array}{lll}1 & 3 & 4 \\
10 & 11\end{array}$ & 45 & 89 \\
\hline $\begin{array}{l}\text { Upper Trapezius, Lower Trapezius, } \\
\text { Seratus Anterior, Latissimus Dorsi, } \\
\text { Anterior Deltoid, Middle Deltoid }\end{array}$ & $\begin{array}{ll}12 & 3 \\
11 & \end{array}$ & 5 & 910 \\
\hline $\begin{array}{l}\text { Upper Trapezius, Lower Trapezius, } \\
\text { Seratus Anterior, Latissimus Dorsi, } \\
\text { Anterior Deltoid, Infraspinatus }\end{array}$ & $\begin{array}{ll}23 & 5 \\
11 & \end{array}$ & 8 & 910 \\
\hline $\begin{array}{l}\text { Upper Trapezius, Lower Trapezius, } \\
\text { Seratus Anterior, Latissimus Dorsi, } \\
\text { Middle Deltoid, Infraspinatus }\end{array}$ & $\begin{array}{lll}1 & 2 & 3 \\
10 & 11\end{array}$ & 5 & 89 \\
\hline
\end{tabular}

92.3

100.0

Middle Deltoid, Infraspinatus

$\begin{array}{llllll}1 & 2 & 3 & 4 & 5 & 9\end{array}$

100.0

99.9

$\begin{array}{llllll}1 & 2 & 3 & 4 & 5 & 9\end{array}$

100.0

1011

$\begin{array}{llllll}1 & 2 & 3 & 4 & 5 & 8\end{array}$

100.0

$$
91011
$$

14.2

$\begin{array}{llllll}1 & 3 & 4 & 5 & 9 & 10\end{array}$

100.0

$\begin{array}{llllll}1 & 2 & 3 & 4 & 5 & 9\end{array}$

100.0 
Upper Trapezius, Lower Trapezius, $\begin{array}{llllll}1 & 3 & 5 & 8 & 9 & 10\end{array}$ Seratus Anterior, Anterior Deltoid, 11

Middle Deltoid, Infraspinatus

Upper Trapezius, Lower Trapezius, $1 \begin{array}{llllll}1 & 2 & 4 & 5 & 9 & 10\end{array}$

Anterior Deltoid, Middle Deltoid

Upper Trapezius, Lower Trapezius, $1 \begin{array}{llllll}1 & 2 & 3 & 4 & 5 & 8\end{array}$

Pectoralis Major, Latissimus Dorsi, 911

Anterior Deltoid, Infraspinatus

Upper Trapezius, Lower Trapezius, 12234458

Pectoralis Major, Latissimus Dorsi, 91011

Middle Deltoid, Infraspinatus

Upper Trapezius, Lower Trapezius, $1 \begin{array}{llllll}1 & 3 & 4 & 5 & 8 & 9\end{array}$

Pectoralis Major, Anterior Deltoid, 1011

Middle Deltoid, Infraspinatus

Upper Trapezius, Lower Trapezius, $1 \begin{array}{llllll}1 & 2 & 3 & 5 & 8 & 9\end{array}$

(atissimus Dorsi, Anterior Deltoid, 1011

Middle Deltoid, Infraspinatus

Upper Trapezius, Seratus Anterior, $\begin{array}{llllll}1 & 2 & 3 & 4 & 10\end{array}$

Pectoralis Major, Latissimus Dorsi, 11

Anterior Deltoid, Middle Deltoid

Upper Trapezius, Seratus Anterior, $\begin{array}{lllllll}1 & 2 & 3 & 4 & 8 & 9\end{array}$

Pectoralis Major, Latissimus Dorsi, 1011

Anterior Deltoid, Infraspinatus

Upper Trapezius, Seratus Anterior, $1 \begin{array}{llllll}1 & 2 & 3 & 4 & 8 & 9\end{array}$

Pectoralis Major, Latissimus Dorsi, 1011

Middle Deltoid, Infraspinatus

Upper Trapezius, Seratus Anterior, $1 \begin{array}{llllll}1 & 3 & 4 & 8 & 9 & 10\end{array}$

Pectoralis Major, Anterior Deltoid, 11

Middle Deltoid, Infraspinatus $\begin{array}{llllll}12 & 3 & 4 & 5 & 9\end{array}$

100.0

99.9

1011

16.7

$\begin{array}{llllll}1 & 2 & 3 & 4 & 5 & 8\end{array}$

100.0

99.8

$\begin{array}{llllll}1 & 2 & 3 & 4 & 5 & 8\end{array}$

100.0

$\begin{array}{llllll}1 & 2 & 3 & 4 & 5 & 8\end{array}$

100.0

99.8

91011

9.1

$\begin{array}{llllll}1 & 2 & 3 & 4 & 5 & 8\end{array}$

100.0

99.8

91011

11.5

$\begin{array}{llllll}1 & 2 & 3 & 4 & 5 & 9\end{array}$

100.0

100.0

1011

11.5

$\begin{array}{llllll}1 & 2 & 3 & 4 & 5 & 8\end{array}$

100.0

99.8

91011

11.5

$\begin{array}{llllll}1 & 2 & 3 & 4 & 5 & 8\end{array}$

100.0

99.8

100.0 $\begin{array}{lll}9 & 10 & 11\end{array}$

$\begin{array}{llllll}1 & 2 & 3 & 4 & 5 & 8\end{array}$

91011 
Upper Trapezius, Seratus Anterior, $\begin{array}{llllll}1 & 2 & 3 & 8 & 9 & 10\end{array}$

(t)

Middle Deltoid, Infraspinatus

Upper Trapezius, Pectoralis Major, $\begin{array}{lllllll}1 & 2 & 3 & 4 & 8 & 9\end{array}$

Latissimus Dorsi, Anterior Deltoid, 1011

Middle Deltoid, Infraspinatus

Lower Trapezius, Seratus Anterior, 11224459910

Pectoralis Major, Latissimus Dorsi, 11

Anterior Deltoid, Middle Deltoid

Lower Trapezius, Seratus Anterior, $2 \begin{array}{llllll}2 & 3 & 4 & 5 & 8 & 9\end{array}$

Pectoralis Major, Latissimus Dorsi, 1011

Anterior Deltoid, Infraspinatus

Pectoralis Major, Latissimus Dorsi, 91011

Middle Deltoid, Infraspinatus

Lower Trapezius, Seratus Anterior, $1 \begin{array}{llllll}1 & 3 & 4 & 5 & 8 & 9\end{array}$

Pectoralis Major, Anterior Deltoid, 1011

Middle Deltoid, Infraspinatus

Lower Trapezius, Seratus Anterior, $\begin{array}{lllllll}1 & 2 & 3 & 5 & 8 & 9\end{array}$

Latissimus Dorsi, Anterior Deltoid, 1011

Middle Deltoid, Infraspinatus

Lower Trapezius, Pectoralis Major, $1 \begin{array}{llllll}1 & 2 & 3 & 4 & 5 & 8\end{array}$

Latissimus Dorsi, Anterior Deltoid, 91011

Middle Deltoid, Infraspinatus

Seratus Anterior, Pectoralis Major, $1 \begin{array}{llllll}1 & 2 & 3 & 4 & 8 & 9\end{array}$

100.0
11.5

$\begin{array}{llllll}1 & 2 & 3 & 4 & 5 & 8\end{array}$

100.0

91011

11.5

$\begin{array}{llllll}1 & 2 & 3 & 4 & 5 & 8\end{array}$

100.0

91011

14.2

12230456

100.0

99.9

1011

4.5

$\begin{array}{lllll}3 & 4 & 5 & 8 & 9\end{array}$

1011

99.8

97.0

0

17.

$\begin{array}{llllll}1 & 2 & 3 & 4 & 5 & 8\end{array}$

99.8

$\begin{array}{lllllll}1 & 2 & 3 & 4 & 5 & 8 & 100.0\end{array}$

91011

$\begin{array}{lllllll}1.2 & 1 & 2 & 3 & 4 & 5 & 8\end{array}$

100.0

99.8

91011

$\begin{array}{lllllll}5.2 & 1 & 2 & 3 & 4 & 5 & 8\end{array}$

100.0

99.8

$\begin{array}{lcl}1 & 10 & 11\end{array}$
1.2

Middle Deltoid, Infraspinatus

\section{7 muscles}

Upper Trapezius, Lower Trapezius, 11224455910

100.0

99.9

atissimus Dorsi, Anterior Deltoid,

Middle Deltoid 
Upper Trapezius, Lower Trapezius, $\begin{array}{lllllll}2 & 3 & 4 & 5 & 8 & 9\end{array}$

Seratus Anterior, Pectoralis Major, 1011

Latissimus Dorsi, Anterior Deltoid

Infraspinatus

Upper Trapezius, Lower Trapezius, $1 \begin{array}{llllll}1 & 2 & 3 & 4 & 5 & 8\end{array}$

Seratus Anterior, Pectoralis Major, 91011

Latissimus Dorsi, Middle Deltoid,

Infraspinatus

Upper Trapezius, Lower Trapezius, $\begin{array}{llllll}1 & 3 & 4 & 5 & 8 & 9\end{array}$

Seratus Anterior, Pectoralis Major, 1011

Anterior Deltoid, Middle Deltoid,

Infraspinatus

Upper Trapezius, Lower Trapezius, $1 \begin{array}{llllll}1 & 2 & 3 & 5 & 8 & 9\end{array}$

Seratus Anterior, Latissimus Dorsi, 1011

Anterior Deltoid, Middle Deltoid,

Infraspinatus

Upper Trapezius, Lower Trapezius, $1 \begin{array}{llllll}1 & 2 & 3 & 4 & 5 & 8\end{array}$

Pectoralis Major, Latissimus Dorsi, 91011

Anterior Deltoid, Middle Deltoid,

Infraspinatus

Pectoralis Major, Latissimus Dorsi, 1011

Anterior Deltoid, Middle Deltoid,

Infraspinatus

Lower Trapezius, Seratus Anterior, $1 \begin{array}{llllll}1 & 2 & 3 & 4 & 5 & 8\end{array}$

100.0
Upper Trapezius, Seratus Anterior, $1 \begin{array}{llllll}1 & 2 & 3 & 4 & 8 & 9\end{array}$

14.3

$\begin{array}{llllll}1 & 2 & 3 & 4 & 5 & 8\end{array}$

100.0

Infraspinatus 
Upper Trapezius, Lower Trapezius, $1 \begin{array}{llllll}1 & 2 & 3 & 4 & 5 & 8\end{array}$

Seratus Anterior, Pectoralis Major, 91011

100.0

Latissimus Dorsi, Anterior Deltoid

Middle Deltoid, Infraspinatus 
Supplementary file S2: Combination of MVIC tests meeting criterion 1 (minimum number of MVIC tests for $>90 \%$ MVA for $>90 \%$ volunteers) and criterion 2 (criterion 1 plus a difference of muscle activation < 5\% MVA between pre-and post-tests for $90 \%$ of the volunteers). Size of the window of the moving average filter: $500 \mathrm{~ms}$ and $2 \mathrm{~s}$. MVIC: Maximum Voluntary Isometric Contraction. (1) empty can, (2) extension prone, (3) seated U $90^{\circ}$, (4) palm press, (5) prone $V$-thumb up, (6) pull down, (7) push forward, (8) rotation $0^{\circ}$, (9) rotation $90^{\circ}$, (10) seated $T$, (11) seated $U$ 125 , (12) shoulder shrug.

\begin{tabular}{|c|c|c|c|c|c|c|c|c|c|}
\hline \multirow[b]{2}{*}{ Muscles } & \multicolumn{5}{|c|}{ Criterion 1} & \multicolumn{4}{|c|}{ Criterion 2} \\
\hline & MVIC tests & $\begin{array}{l}\# \text { of } \\
\text { (\%) }\end{array}$ & subjects & $\begin{array}{l}\text { Level of activation } \\
(\% \text { MVA) }\end{array}$ & $\begin{array}{l}\text { Variation } \\
\text { (\% MVA) }\end{array}$ & MVIC tests & $\begin{array}{lll}\# & \text { of } & \text { subjects } \\
(\%) & & \end{array}$ & $\begin{array}{l}\text { Level of activation } \\
(\% \text { MVA) }\end{array}$ & $\begin{array}{l}\text { Variation } \\
\text { (\% MVA) }\end{array}$ \\
\hline \multicolumn{10}{|l|}{$500 \mathrm{~ms}$} \\
\hline Upper Trapezius & $\begin{array}{llll}1 & 5 & 10 & 11\end{array}$ & 92 & & 99 & 8.0 & $\begin{array}{lllll}1 & 3 & 5 & 10 & 11\end{array}$ & 100 & 100 & 1.4 \\
\hline Lower Trapezius & 59 & 100 & & 98 & 13.8 & 25910 & 100 & 100 & 3.7 \\
\hline Seratus Anterior & 31011 & 100 & & 99 & 10.9 & 1391011 & 100 & 100 & 2.1 \\
\hline Pectoralis Major & 4 & 100 & & 99 & 19.5 & 34 & 100 & 100 & 1.9 \\
\hline Latissimus Dorsi & 2 & 100 & & 100 & 0.0 & 2 & 100 & 100 & 0.0 \\
\hline Anterior Deltoid & 1311 & 92 & & 98 & 21.1 & 1341011 & 100 & 100 & 0.0 \\
\hline Middle Deltoid & $\begin{array}{llll}1 & 5 & 10 & 11\end{array}$ & 100 & & 100 & 0.0 & 151011 & 100 & 100 & 0.0 \\
\hline Infraspinatus & 2789 & 92 & & 98 & 30.6 & $\begin{array}{llllll}2 & 3 & 6 & 8 & 9 & 11\end{array}$ & 100 & 99 & 4.0 \\
\hline All muscles & $\begin{array}{lllllll}1 & 2 & 3 & 4 & 8 & 9 & 10 \\
11 & & & & & & \end{array}$ & 92 & & 96 & 24.8 & $\begin{array}{ccccccc}1 & 2 & 3 & 4 & 5 & 7 & 8 \\
9 & 10 & 11 & & & & \end{array}$ & 100 & 100 & 3.9 \\
\hline \multicolumn{10}{|l|}{$2 \mathrm{~s}$} \\
\hline Upper Trapezius & 1311 & 92 & & 98 & 8.3 & $\begin{array}{lllll}1 & 3 & 5 & 10 & 11\end{array}$ & 100 & 100 & 1.0 \\
\hline Lower Trapezius & 59 & 100 & & 98 & 8.8 & $\begin{array}{lllll}3 & 5 & 6 & 9 & 10\end{array}$ & 100 & 99 & 4.2 \\
\hline
\end{tabular}




\begin{tabular}{|c|c|c|c|c|}
\hline Seratus Anterior & 1011 & 92 & 97 & 21.9 \\
\hline Pectoralis Major & 4 & 100 & 99 & 19.4 \\
\hline Latissimus Dorsi & 2 & 100 & 100 & 0.0 \\
\hline Anterior Deltoid & 1311 & 92 & 99 & 15.4 \\
\hline Middle Deltoid & 11011 & 92 & 98 & 9.1 \\
\hline Infraspinatus & 2389 & 92 & 98 & 11.8 \\
\hline All muscles & $\begin{array}{lllllll}1 & 2 & 3 & 4 & 5 & 8 & 9 \\
10 & 11 & & & & \end{array}$ & 100 & 100 & 0.0 \\
\hline
\end{tabular}

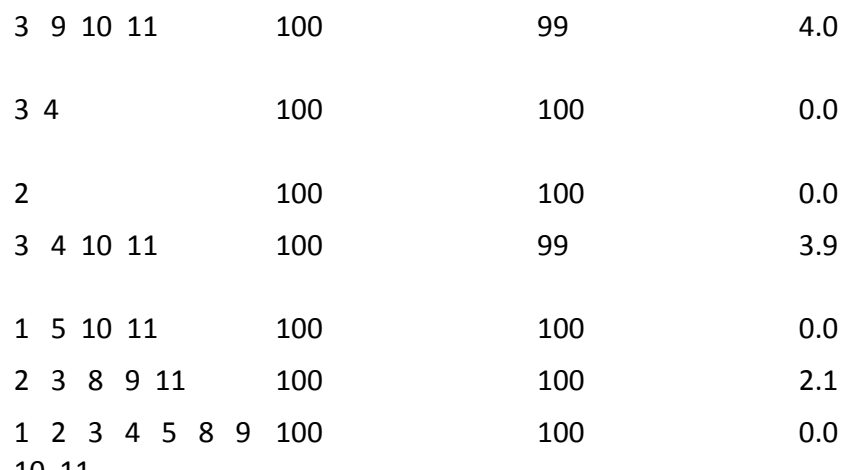

